\title{
CCL3-CCR5 axis contributes to progression of esophageal squamous cell carcinoma by promoting cell migration and invasion via Akt and ERK pathways
}

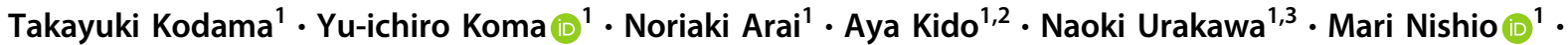 \\ Manabu Shigeoka ${ }^{1} \cdot$ Hiroshi Yokozaki ${ }^{1}$
}

Received: 9 December 2019 / Revised: 8 May 2020 / Accepted: 8 May 2020 / Published online: 26 May 2020

(c) The Author(s) 2020. This article is published with open access

\begin{abstract}
Tumor-associated macrophages (TAMs) contribute to the progression and mortality of various malignancies. We reported that high numbers of infiltrating TAMs were significantly associated with tumor progression and poor prognosis in esophageal squamous cell carcinoma (ESCC). In our previous investigation of TAMs' actions in ESCC, we compared gene expression profiles between peripheral blood monocyte (PBMo)-derived macrophages and TAM-like macrophages stimulated with conditioned media of ESCC cell lines. Among the upregulated genes in the TAM-like macrophages, we focused on CC chemokine ligand 3 (CCL3), which was reported to contribute to tumor progression in several malignancies. Herein, we observed that not only TAMs but also ESCC cell lines expressed CCL3. A CCL3 receptor, CC chemokine receptor 5 (CCR5) was expressed in the ESCC cell lines. Treating the ESCC cell lines with recombinant human (rh)CCL3 induced the phosphorylations of Akt and ERK, which were suppressed by CCR5 knockdown. Migration and invasion of ESCC cells were promoted by treatment with rhCCL3 and co-culture with TAMs. TAMs/rhCCL3-promoted cell migration and invasion were suppressed by inhibition of the CCL3-CCR5 axis, PI3K/Akt, and MEK/ERK pathways. Treatment with rhCCL3 upregulated MMP2 and VEGFA expressions in ESCC cell lines. Our immunohistochemical analysis of 68 resected ESCC cases showed that high expression of CCL3 and/or CCR5 in ESCC tissues was associated with poor prognosis. High CCR5 expression was associated with deeper invasion, presence of vascular invasion, higher pathological stage, higher numbers of infiltrating CD204+ TAMs, and higher microvascular density. High expression of both CCL3 and CCR5 was an independent prognostic factor for disease-free survival. These results suggest that CCL3 derived from both TAMs and cancer cells contributes to the progression and poor prognosis of ESCC by promoting cell migration and invasion via the binding of CCR5 and the phosphorylations of Akt and ERK. The CCL3-CCR5 axis could become the target of new therapies against ESCC.
\end{abstract}

Supplementary information The online version of this article (https:// doi.org/10.1038/s41374-020-0441-4) contains supplementary material, which is available to authorized users.

Yu-ichiro Koma

koma069601119@gmail.com

1 Division of Pathology, Department of Pathology, Kobe University Graduate School of Medicine, Kobe, Japan

2 Department of Molecular Pathology, Institute of Biomedical and Health Sciences, Hiroshima University, Hiroshima, Japan

3 Division of Gastro-intestinal Surgery, Department of Surgery, Kobe University Graduate School of Medicine, Kobe, Japan

\section{Introduction}

Worldwide, esophageal cancer was the seventh most common cancer and the sixth leading cause of cancer-related deaths, with an estimated 572,000 new cases (3\% of all cancers) and 509,000 deaths (5\% of all cancers) in 2018 [1]. The prognosis of esophageal cancer is poor, with an $18 \%$ overall 5-year survival [2]. There are two main histological subtypes: esophageal squamous cell carcinoma (ESCC) and adenocarcinoma. In the Western countries, adenocarcinoma is predominant, but in Asia and Sub-Saharan Africa, including Japan, ESCC accounts for approximately $90 \%$ of esophageal cancer cases [1-3]. ESCC is characterized by a high incidence of lymph node metastasis (37\%), which closely correlates poor prognosis [4]. Even among ESCCs 
localized in the submucosa, $34 \%$ of the cases have lymph node metastases, and $22 \%$ of the cases have recurrences [5]. A better understanding of the molecular pathogenesis of ESCC is thus necessary to establish novel therapies and biomarkers for this cancer.

Recent evidence indicates that not only the molecular mechanisms that function in tumor cells themselves but also those that function in their surrounding environment hold the key to tumor development in many types of cancer, including ESCC [6, 7]. The tumor microenvironment is composed of tumor cells, stromal non-tumor cells (including fibroblasts, monocytes/macrophages, neutrophils, lymphocytes, and vascular cells), and extracellular matrix [6]. Macrophages are one of the most abundant components of the tumor microenvironment, and they are divided into two phenotypes from an oncologic viewpoint: tumorsuppressive (M1) and tumor-supportive (M2) cells. M1 macrophages are classically activated by interferon-gamma and are characterized by high expressions of proinflammatory cytokines such as interleukin (IL)-1, IL-6, IL-12, IL-23, and tumor necrosis factor-alpha. M2 macrophages are alternatively activated and are characterized by anti-inflammatory cytokines such as IL-4, IL-10, IL-13, and tissue growth factor-beta [8-11].

In the microenvironment in various malignancies, tumorassociated macrophages (TAMs) are polarized into the M2 phenotype with $\mathrm{IL}-4 / \mathrm{IL}-10^{\text {high }}$, IL-12 ${ }^{\text {low }}$, cell surface receptors including scavenger receptors CD163 and CD204, and a mannose receptor $\mathrm{CD} 206$ [8, 10, 11]. In various malignancies, higher numbers of infiltrating TAMs were reported to be associated with worse prognosis by promoting tumor cell proliferation, invasion, angiogenesis, metastasis formation, and immune suppression [9, 11].

We have demonstrated that a high number of infiltrating CD204 ${ }^{+}$TAMs is associated with higher histological grade, deeper invasion, lymph node metastasis, higher pathological stage, lymphatic invasion, vascular invasion, microvascular density, and poor disease-free survival in ESCC [12]. To explore the functions of TAMs in ESCC, we had compared gene expression profiles between peripheral blood monocyte (PBMo)-derived macrophages and TAMlike macrophages stimulated with the conditioned media of ESCC cell lines by performing a cDNA microarray analysis [13]. Among the upregulated molecules in the TAM-like macrophages, we observed that growth differentiation factor 15, neural cell adhesion molecule, and CXC chemokine ligand 8 (CXCL8, also known as IL-8) contribute to the tumor cell migration, progression, and poor prognosis of ESCC [13-15].

In the present study, we focused on one of the genes that was upregulated in TAM-like macrophages: $C C$ chemokine ligand 3 (CCL3). CCL3, also known as macrophage inflammatory protein-1 $\alpha$ (MIP-1 $1 \alpha)$, is a member of the CC chemokine family. CC chemokine receptor 1 (CCR1) and CC chemokine receptor 5 (CCR5) are receptors of CCL3 [16]. The involvement of CCL3 was reported in the progression of various malignancies. For example, the CCL3-CCR1 axis has been associated with the progression of hepatocellular carcinoma [17], whereas the CCL3-CCR5 axis has been associated with osteolysis in multiple myeloma [18, 19], lung metastasis in murine renal cell carcinoma [20], cell migration, and invasion in chondrosarcoma [21], infiltration of cancer-associated fibroblasts in murine colitis-associated colorectal carcinoma [22], and angiogenesis in osteosarcoma [23]. Both the CCL3-CCR1 and CCL3-CCR5 axes are associated with leukemogenesis in chronic myeloid leukemia $[24,25]$ and the progression of oral squamous cell carcinoma [26, 27].

CCR5 is a chemokine receptor and a member of the Gprotein coupled receptor family that is usually expressed in memory $\mathrm{T}$ lymphocytes, macrophages, dendritic cells, platelets, neurons, astrocytes, fibroblasts, smooth muscle cells, and capillary endothelial cells [16, 28-30]. CCR5 is not only a receptor for CCL3 but also a receptor for the following members of the CC chemokine family: CCL4, CCL5, CCL8, and CCL3 like-1 (CCL3L1) [29, 30]. CCR5 is expressed in various neoplastic cells including oral squamous cell carcinoma [27], murine renal cell carcinoma [20], chondrosarcoma [21], osteosarcoma [23], breast cancer [31-34], pancreatic cancer [35], salivary adenoid cystic carcinoma [36], and Hodgkin lymphoma [37]. CCR5 expressed in neoplastic cells contributes to cell migration, invasion and tumor progression not only via the CCL3-CCR5 axis $[20,21,23,27]$, but also via the CCL5-CCR5 axis in breast cancer, pancreatic cancer, salivary adenoid cystic carcinoma, Hodgkin lymphoma, and ESCC [31-38]. CCL5-CCR5 and/or CCL8-CCR5 axes are also involved in accumulation of $\mathrm{CCR} 5^{+}$regulatory $\mathrm{T}$ cells in tumor microenvironment in melanoma, breast cancer, and ovarian cancer [39-41]. However, the roles of CCL3-CCR5 axis in ESCC have not been revealed; therefore, we conducted the present study to address these profiles.

\section{Materials and methods}

\section{ESCC cell lines and cell cultures}

We purchased three ESCC cell lines from the RIKEN BioResource Center (Tsukuba, Japan): TE-8 (moderately differentiated ESCC), TE-9 (poorly differentiated ESCC), and TE-15 (well differentiated ESCC). Het-1A, a normal human esophageal squamous epithelial cell line immortalized SV40-T antigen transfection, was purchased from the American Type Culture Collection ${ }^{\circledR}$ (Manassas, VA) [42]. The individuality of the TE series ESCC cell lines was 
confirmed by a short tandem repeat analysis at RIKEN and at the Cell Resource Center for Biomedical Research, Institute of Development, Aging and Cancer, Tohoku University (Sendai, Japan) [43]. All three ESCC cell lines were confirmed to be mycoplasma-negative by a Venor ${ }^{\circledR}$ Gem Classic Mycoplasma Detection kit (Minerva Biolabs, Berlin, Germany) and cultured in RPMI-1640 medium (FUJIFILM Wako Pure Chemical, Osaka, Japan) supplemented with $10 \%$ fetal bovine serum (FBS) (SigmaAldrich, St. Louis, MO) and $1 \%$ antibiotic-antimycotic (Invitrogen, Carlsbad, CA). The Het-1A cell line was confirmed to be free of human pathogenic virus using a PCRbased assay for human immunodeficiency virus (HIV), hepatitis B virus, human papilloma virus, Epstein-Barr virus, and cytomegalovirus and cultured in BEGM ${ }^{\mathrm{TM}}$ Bronchial Epithelial Cell Growth Medium BulletKit ${ }^{\mathrm{TM}}$ (\#CC-3170; Lonza, Walkersville, MD).

The conditioned medium of the TE series ESCC cell lines (TECM; i.e., TE-8CM, TE-9CM, and TE-15CM) were prepared by plating $5 \times 10^{6}$ tumor cells in $10 \mathrm{ml}$ of complete medium on $100-\mathrm{mm}$ dishes for $24 \mathrm{~h}$. The medium was then changed to complete Dulbecco's modified Eagle's medium (DMEM; FUJIFILM Wako Pure Chemical) supplemented with $10 \%$ human $\mathrm{AB}$ serum (Lonza). Two days later, the supernatants were harvested, centrifuged, and stored in aliquots at $-80^{\circ} \mathrm{C}$.

\section{Macrophage and TAM-like macrophage cultures}

Peripheral blood mononuclear cells (PBMCs) were obtained from healthy volunteer donors with written informed consents. CD14 ${ }^{+}$PBMos were purified from PBMCs by positive selection using an auto $\mathrm{MACS}^{\circledR}$ Pro Separator (Miltenyi Biotec, Bergisch Gladbach, Germany). Then, $5 \times$ $10^{6}$ PBMos were cultured on six-well plates with macrophage-colony stimulating factor $(25 \mathrm{ng} / \mathrm{ml}$; R\&D Systems, Minneapolis, MN) for 6 days for the induction of macrophages differentiation. PBMo-derived macrophages were treated with $50 \%$ TECM for 2 days for the induction of TAM-like polarization. We named the TAM-like macrophages polarized by TE-8CM, TE-9CM, and TE-15CM as, respectively, TAM8, TAM9, and TAM15 cells.

\section{Reagents}

Recombinant human CCL3/MIP-1 $\alpha$ protein (rhCCL3, catalog \#270-LD), the neutralizing antibody against CCL3 (\#AF-270), and normal goat IgG control (\#AB-108-C) were purchased from R\&D Systems. The inhibitors against PI3K (LY294002, \#9901) and MEK (PD98059, \#9900) were purchased from Cell Signaling Technology (Danvers, MA). The CCR5 antagonist, Maraviroc (\#PZ0002) was purchased from Sigma-Aldrich.

\section{CCR5 knockdown by small interfering RNA (siRNA)}

For the CCR5 knockdown by siRNA, $5 \times 10^{5}$ TE- 8 , TE-9, and TE- 15 cells on $60 \mathrm{~mm}$ dishes were transfected by $20 \mathrm{nM}$ siRNA against CCR5 (siCCR5, \#sc-35062; Santa Cruz Biotechnology) using Lipofectamine ${ }^{\circledR}$ RNAiMAX (Invitrogen) for 2 days. Control siRNA (Sigma-Aldrich) was used as the negative control (siNC).

\section{Reverse transcription PCR (RT-PCR) and quantitative RT-PCR}

Total RNA was extracted from cultured cells with the use of an RNeasy Mini Kit (Qiagen, Hilden, Germany). Reverse transcription-polymerase chain reaction (RTPCR) amplifications of CCL3, CCR1, CCR5, MMP2, $M M P 9, V E G F A$, and the internal control gene $G A P D H$ were performed. PCR products were subjected to electrophoresis in a $2 \%$ agarose gel. The primers used for RTPCR were: CCL3, 5'-TCT GCA TCA CTT GCT GCT GAC AC-3' (forward), 5'-CAC TCA GCT CCA GGT CGCTGA C-3' (reverse); CCR1, 5'-CAC GGA CAA AGT CCC TTG G-3' (forward), 5'-CAA AGG CCC TCT CGT TCA C-3' (reverse); CCR5, 5'-GAC ATC CGT TCC CCT ACA AG-3' (forward), 5'-AGA TGA ACA CCA GTG AGT AGA G-3' (reverse); GAPDH, 5'-ACC ACA GTC CAT GCC ATC AC-3' (forward), 5'-TCC ACC ACC CTG TTG CTG TA-3' (reverse).

A quantitative RT-PCR was performed using the following probes: CCL3 (Hs00234142_m1), MMP2 (Hs01548727_m1), MMP9 (Hs00234579_m1), VEGFA (Hs00900054_m1), and GAPDH (Hs02786624_g1) (Applied Biosystems, Foster City, CA) on an ABI StepOne Real-time PCR system (Applied Biosystems) using TaqMan Gene Expression Master Mix (Applied Biosystems). The threshold cycle $(\mathrm{Ct})$ values were determined by plotting the observed fluorescence against the cycle number. $\mathrm{Ct}$ values were analyzed using the comparative threshold cycle method and normalized to those of GAPDH. We used the following formula to estimate the relative gene expression levels: relative expression $=2^{-(\mathrm{Ct}[\text { target gene }]-\mathrm{Ct}[G A P D H])}$.

\section{Enzyme-linked immunosorbent assay (ELISA)}

For an ELISA of CCL3, $5 \times 10^{5}$ PBMo-derived macrophages, TAM8 cells, TAM9 cells, TAM15 cells, and $2 \times$ $10^{6}$ of each of the ESCC cell lines were incubated on sixwell plates with $2 \mathrm{ml}$ of serum-free DMEM. Two days later, the media were collected and applied to a Quantikine ${ }^{\circledR}$ ELISA Human CCL3 immunoassay (\#DMA00; R\&D Systems). We determined the optical density (OD) using a Microplate Reader Infinite ${ }^{\circledR} 200$ PRO (Tecan, Männedorf, Switzerland). 


\section{Western blotting}

Cells were lysed in cell lysis buffer $(50 \mathrm{mM}$ Tris- $\mathrm{HCl} \mathrm{pH}$ $7.5,125 \mathrm{mM} \mathrm{NaCl}, 5 \mathrm{mM}$ EDTA and $0.1 \%$ Triton X-100) containing $1 \%$ protease inhibitor and $1 \%$ phosphatase inhibitor cocktail (Sigma-Aldrich). The resulting lysates were separated on $5-20 \%$ or $15-20 \%$ s sodium dodecyl sulfate (SDS) polyacrylamide gels for SDS-polyacrylamide gel electrophoresis (PAGE) and then transferred to a membrane with an iBlot ${ }^{\circledR}$ Gel Transfer Stack (Invitrogen). The membrane was blocked with 5\% skim milk and then incubated with the primary antibody at $4{ }^{\circ} \mathrm{C}$ overnight and then with secondary antibodies for $90 \mathrm{~min}$ at the room temperature. The protein bands were detected with ImmunoStar $^{\circledast}$ Reagents (FUJIFILM Wako Pure Chemical). Densitometric analyses of bands were performed with ImageJ software ver. 1.8.0 (National Institutes of Health, Bethesda, MD).

The primary antibodies were as follows. Rabbit polyclonal antibody against CCR1 (1:250, \#ab1681; Abcam, Cambridge, UK), mouse monoclonal antibody against CCR5 (1:100, \#sc32304; Santa Cruz Biotechnology), rabbit polyclonal antibody against CCL3 (1:100, \#LS-C384561; LifeSpan BioSciences, Seattle, WA), and the following rabbit monoclonal antibodies (all from Cell Signaling Technology): phosphorylated Akt (Ser473; 1:250, \#4060), phosphorylated Akt (Thr308; 1:250, \#2965), total Akt (1:500, \#9272), phosphorylated ERK1/2 (Thr202/Tyr204; 1:250, \#9101), total ERK1/2 (1:500, \#9102), and $\beta$-actin (1:1000, \#4970).

The secondary antibodies were horseradish peroxidase (HRP)-linked donkey anti-rabbit IgG (1:1000, \#NA934V) and HRP-linked sheep anti-mouse IgG (1:1000, \#NA931V), both were purchased from GE Healthcare Life Sciences (Little Chalfont, UK).

\section{Immunofluorescence (IF)}

For the IF examination, $1 \times 10^{5}$ cultured cells on coverslips were fixed with methanol for $10 \mathrm{~min}$ at $-20{ }^{\circ} \mathrm{C}$ and incubated with primary antibodies against CCR5 (1:25, \#sc32304; Santa Cruz Biotechnology), CCL3 (1:100, \#LSC384561; LifeSpan BioSciences), and CD204 (1:100, \#SRA-E5; TransGenic, Kobe, Japan) at $4{ }^{\circ} \mathrm{C}$ overnight. The cells were then incubated with AlexaFluor- $488^{\circledR}$ conjugated donkey anti-rabbit secondary antibody, AlexaFluor- $488^{\circledR}$ conjugated donkey anti-mouse secondary antibody, and Cy3-conjugated donkey anti-mouse IgG secondary antibody (1:200; Jackson ImmunoResearch Laboratories, West Grove, PA). The nuclei were stained by $4^{\prime}, 6$-diamidino-2phenylindole (DAPI, 1:1000; Vector Laboratories, Burlingame, CA). Images were taken with a Zeiss LSM 700 laserscanning microscope and analyzed using the LSM software ZEN 2009 (Carl Zeiss, Oberkochen, Germany).

\section{Transwell migration and invasion assays}

For the migration assay, $2 \times 10^{5}$ TE- 8 cells or $1 \times 10^{5}$ TE- 9 cells in $300 \mu \mathrm{l}$ of medium with $0.1 \%$ FBS were placed in the upper transwell inserts with an 8- $\mu \mathrm{m}$ pore filter (BD Falcon, Lincoln Park, NY) in 24-well plates. For the invasion assay, the same number of TE- 8 or TE- 9 cells in the same medium were placed in the inserts of a Corning ${ }^{\circledR}$ BioCoat $^{\mathrm{TM}}$ Matrigel $^{\circledR}$ Invasion Chamber (Corning, Tewksbury, MA) in 24-well plates, and then $800 \mu \mathrm{l}$ of medium containing $100 \mathrm{ng} / \mathrm{ml}$ rhCCL3 or $1 \times 10^{5}$ TAMs was placed in the lower chamber. Next, $20 \mu \mathrm{M}$ LY294002, $20 \mu \mathrm{M}$ PD98059, or $20 \mu \mathrm{g} / \mathrm{ml}$ Maraviroc was added to the upper chambers, and the neutralizing antibody against CCL3 (400 ng/ml) was added to the lower chambers. The plates were then incubated for $24 \mathrm{~h}$ (for the migration assay) or $48 \mathrm{~h}$ (for the invasion assay) at $37{ }^{\circ} \mathrm{C}$ in $5 \% \mathrm{CO}_{2}$. The cells were fixed in methanol for $1 \mathrm{~min}$ and stained with Diff-Quik ${ }^{\circledR}$ (Sysmex, Kobe, Japan). Cells on the upper side of the filters were removed with cotton-tipped swabs. Five images at $\times 200$ magnification were obtained from each membrane with a CCD camera (Olympus, Tokyo, Japan), and the number of cells was counted. The percent migration or invasion was calculated by dividing the number of cells by that in the negative control (without rhCCL3, co-cultured TAMs, inhibitors, Maraviroc, or the neutralizing antibody of CCL3).

\section{Cell survival and growth assays}

For the cell survival assay, $1 \times 10^{4}$ of each of the ESCC cell lines were plated in 96-well plates with $100 \mu \mathrm{l}$ of serum-free medium containing 10 or $100 \mathrm{ng} / \mathrm{ml}$ rhCCL3. For the cell growth assay, $5 \times 10^{3}$ of each of the ESCC cell lines were plated in medium supplemented with $0.1 \%$ FBS. The plates were incubated for $72 \mathrm{~h}$, and an MTS assay was performed: $20 \mu \mathrm{l}$ CellTiter $96^{\circledR}$ AQueous One Solution Reagent (Promega, Madison, WI) was added to the medium, and then the $\mathrm{OD}$ at $492 \mathrm{~nm}$ was determined.

\section{ESCC tissue samples and immunohistochemistry}

We examined a total of 68 human ESCC samples that were surgically resected at Kobe University Hospital (Kobe, Japan) during the years from 2005 to 2010 . None of the ESCC patients had received neoadjuvant chemotherapy or radiotherapy before surgery. Informed consent for the use of their tissue samples was obtained from all patients, and the study was approved by the Kobe University Institutional Review Board. All resected specimens were fixed with $10 \%$ formalin, embedded in paraffin wax, and sliced at 4- $\mu \mathrm{m}$ thickness. Each sample was categorized based on the 11th edition of Japanese Classification of Esophageal 
A

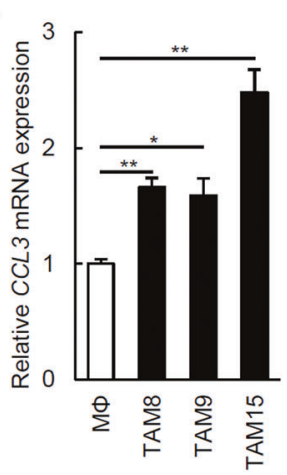

D

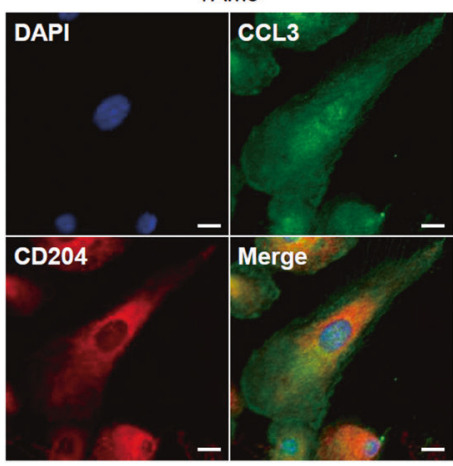

B

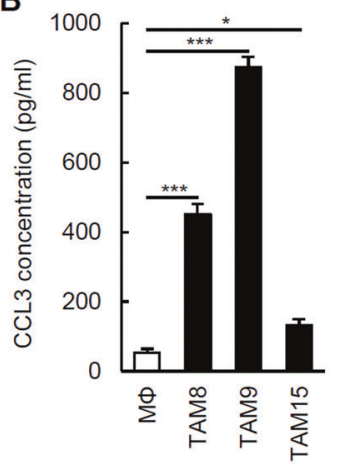

C

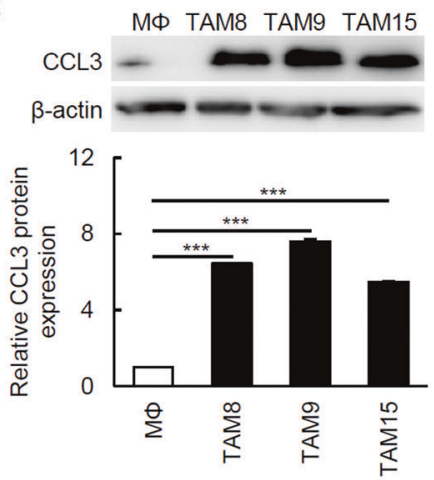

TAM9
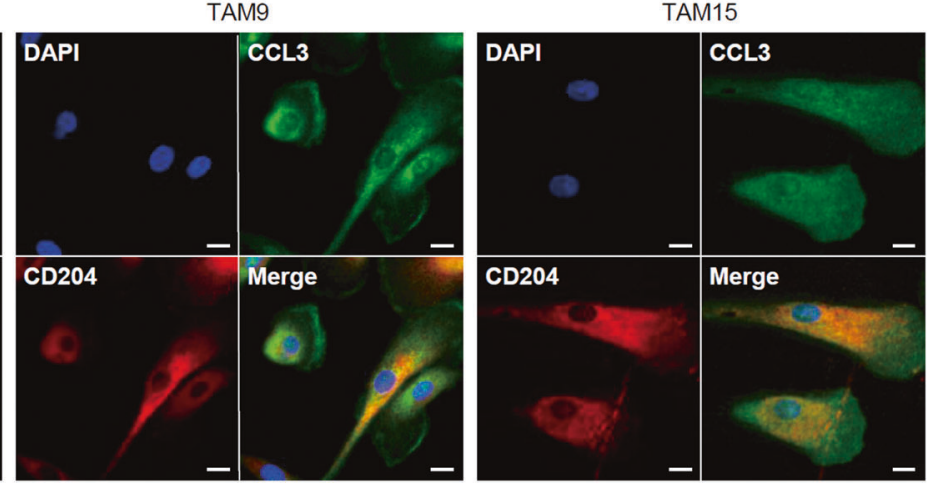

Fig. 1 CCL3 expression in PBMo-derived macrophages and TAMlike macrophages. a The $C C L 3 \mathrm{mRNA}$ expression levels of macrophages (MФ) and TAM-like macrophages (TAM8, TAM9, and TAM15) were determined by quantitative RT-PCR and normalized to GAPDH expression. Data are mean $\pm \operatorname{SEM}(n=3, * p<0.05, * * p<$ 0.01). Compared with M $\Phi$, TAM8, TAM9, and TAM15 expressed significantly higher levels of CCL3 mRNA. b The CCL3 concentration in conditioned medium of MФ, TAM8, TAM9, and TAM15. Protein levels were measured by ELISA. Results are mean \pm SEM $(n=4, * p$ $<0.05, * * * p<0.001)$. TAM8, TAM9, and TAM15 secreted significantly more CCL3 compared with MФ. c Western blotting was conducted with total protein from МФ, TAM8, TAM9, and TAM15 using antibodies against CCL3 and $\beta$-actin. Higher levels of CCL3 expression was detected in TAM8, TAM9, and TAM15 compared with $\mathrm{M} \Phi$. The densitometric analyses were performed by ImageJ software. Results are mean \pm SEM $(* * * p<0.001)$. d The coexpression of CCL3 and CD204 in TAM8, TAM9, and TAM15. Double immunofluorescence was performed using antibodies against CCL3 (green) and CD204 (red). TAM8, TAM9, and TAM15 expressed both CCL3 and CD204. Nuclei were stained by DAPI (blue). Magnification: $\times 600$. Scale bar: $10 \mu \mathrm{m}$.

"high" (stronger than the intensity in muscularis propria). The infiltrating number of TAMs was evaluated by CD68, CD163, and CD204 immunohistochemistry as previously described [12]. Microvascular density was evaluated by CD34 immunohistochemistry as previously described [12]. The evaluation and scoring were performed by three independent pathologists (authors TK, YK, and HY).

\section{Statistical analyses}

All experiments were performed in triplicate and conducted independently at least three times. The results are expressed as the mean \pm standard error (SEM), and statistical significance was analyzed by two-sided Student's $t$ test. The relationships between clinicopathological factors and immunohistochemistry were estimated by $\chi^{2}$-test. Overall, the disease-free and cause-specific survival curves were estimated by the Kaplan-Meier method and compared by log-rank test. The significance of parameters in the 
A

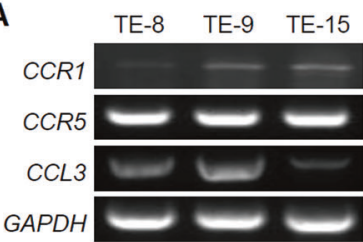

B

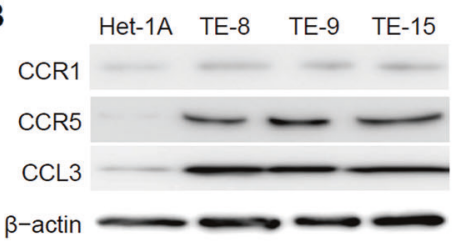

C

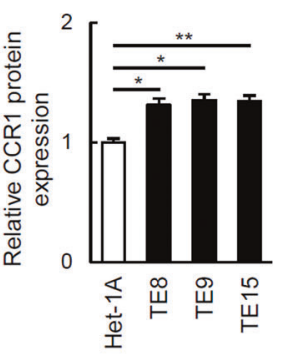

E

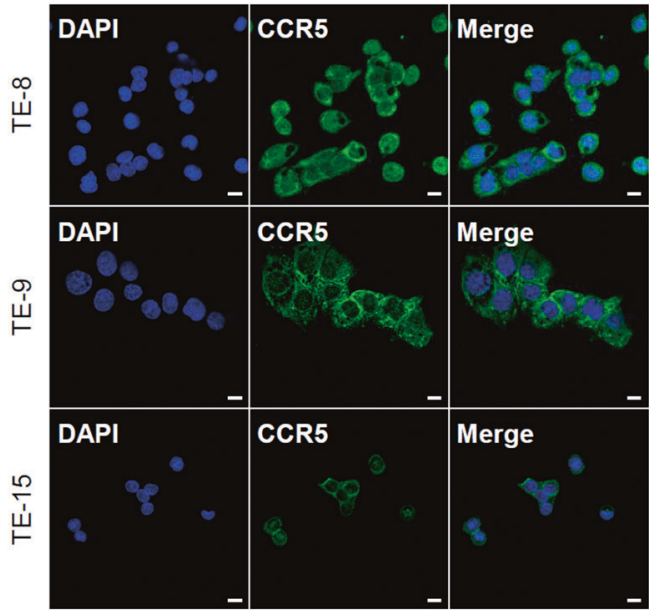

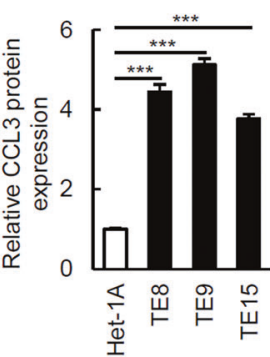
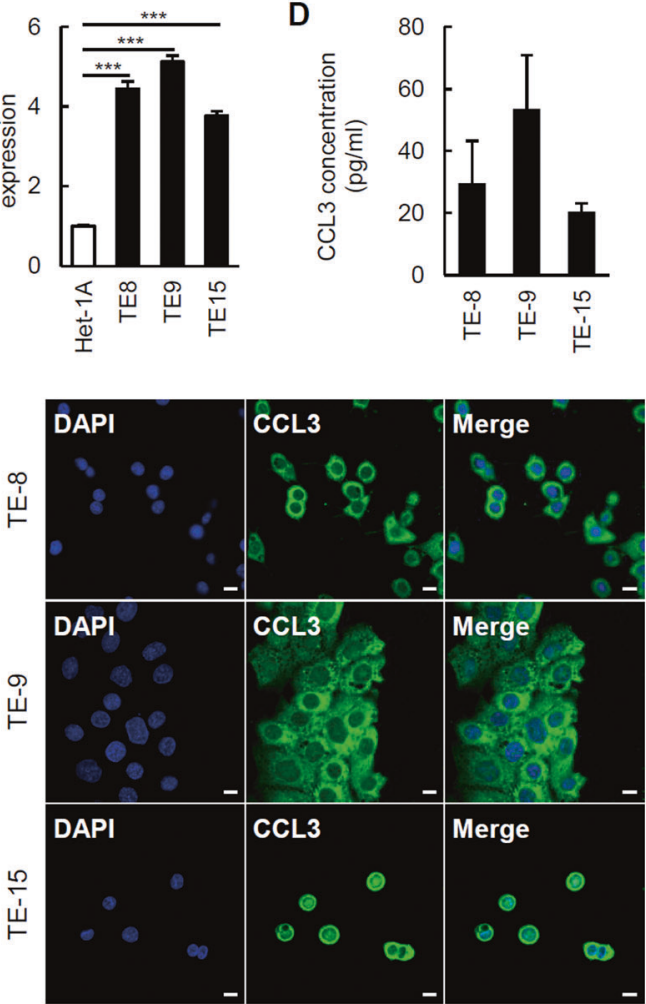

Fig. 2 The expression of CCR1, CCR5, and CCL3 in the ESCC cell lines. a CCR1, CCR5, and CCL3 mRNA expressions in TE-8, TE9 , and TE-15 cells were detected by RT-PCR. The results of western blotting (b) and their densitometric analyses (c, mean \pm SEM, $* p<$ $0.05, * * p<0.01, * * * p<0.01)$. CCR1, CCR5, and CCL3 protein expressions in TE-8, TE-9, and TE-15 cells were significantly higher than those of Het-1A cells. However, CCR1 expression levels in TE-8, TE-9, and TE-15 cells were relatively lower than CCL3 and CCR5

univariate and multivariate analyses was tested using the Cox proportional hazard regression model. A $p$ value $<0.05$ was considered significant. The statistical analyses were carried out using SPSS Statistics ver. 22 (IBM, Chicago, IL).

\section{Results}

\section{The TAM-like macrophages expressed CCL3}

We first confirmed the expression level of CCL3 in TAMlike macrophages. Compared with the CCL3 mRNA expression level in the PBMo-derived TAM-like expression levels. d CCL3 concentration in conditioned medium of TE-8, TE-9, and TE-15 cells. Protein levels were measured by ELISA. Results are mean $\pm \operatorname{SEM}(n=4)$. CCL3 secretion was detected from TE-8, TE-9, and TE-15 cells. e Immunofluorescence using anti-CCR5 or anti-CCL3 (green) antibody on TE-8, TE-9, and TE-15 cells. Nuclei were stained by DAPI (blue). CCL3 and CCR5 were expressed in TE8, TE-9, and TE-15 cells. Magnification: $\times 400$. Scale bar: $10 \mu \mathrm{m}$.

macrophages ( $1.0 \pm 0.0$-folds), the expression levels were significantly higher in the PBMo-derived TAM-like macrophages polarized by TE-8CM (TAM8 cells, $1.7 \pm 0.1$ fold, $p=0.002$ ), TE-9CM (TAM9 cells, $1.6 \pm 0.1$-fold, $p=$ 0.018 ), and TE-15CM (TAM15 cells, $2.5 \pm 0.2$-fold, $p=$ 0.002) (Fig. 1a). The ELISA results showed that the CCL3 concentrations of the conditioned medium of TAM8 cells $(451.0 \pm 29.1 \mathrm{pg} / \mathrm{ml}, p<0.001)$, TAM9 cells $(873.0 \pm 31.2$ $\mathrm{pg} / \mathrm{ml}, p<0.001)$, and TAM15 cells $(131.5 \pm 17.3 \mathrm{pg} / \mathrm{ml}$, $p=0.016)$ were significantly higher than that of the PBModerived macrophages $(52.7 \pm 11.3 \mathrm{pg} / \mathrm{ml})$ (Fig. 1b). The western blotting using antibodies against CCL3 detected much higher CCL3 expressions in the TAM8 cells $(6.4 \pm$ 0.0 -fold, $p<0.001)$, TAM9 cells $(7.6 \pm 0.1$-fold, $p<0.001$ ), 
A

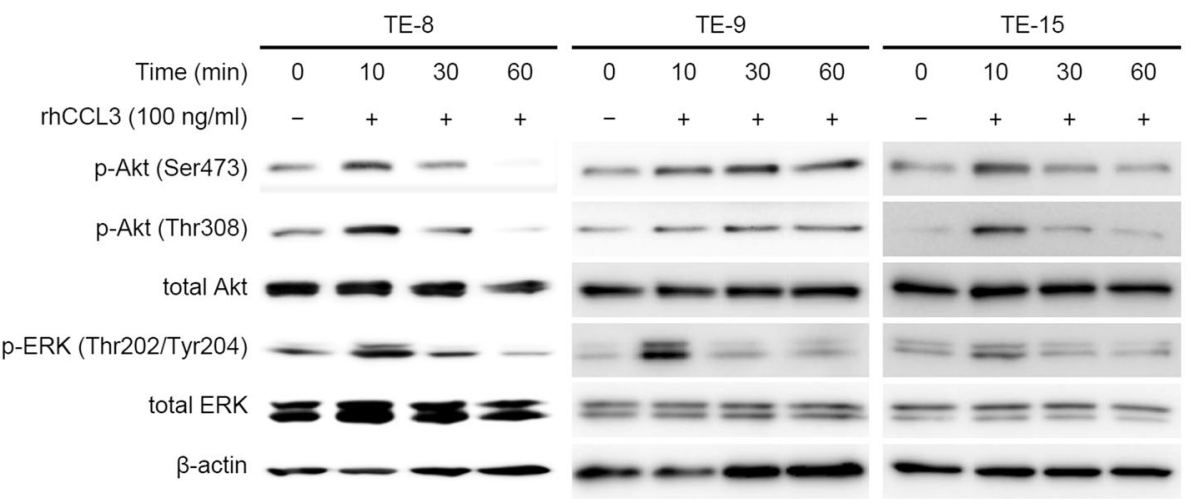

B

\begin{tabular}{|c|c|c|}
\hline TE-8 & TE-9 & TE-15 \\
\hline siCCR5 & siCCR5 & siCCR5 \\
\hline & 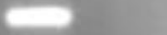 & 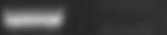 \\
\hline & 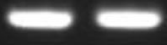 & 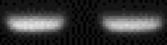 \\
\hline
\end{tabular}
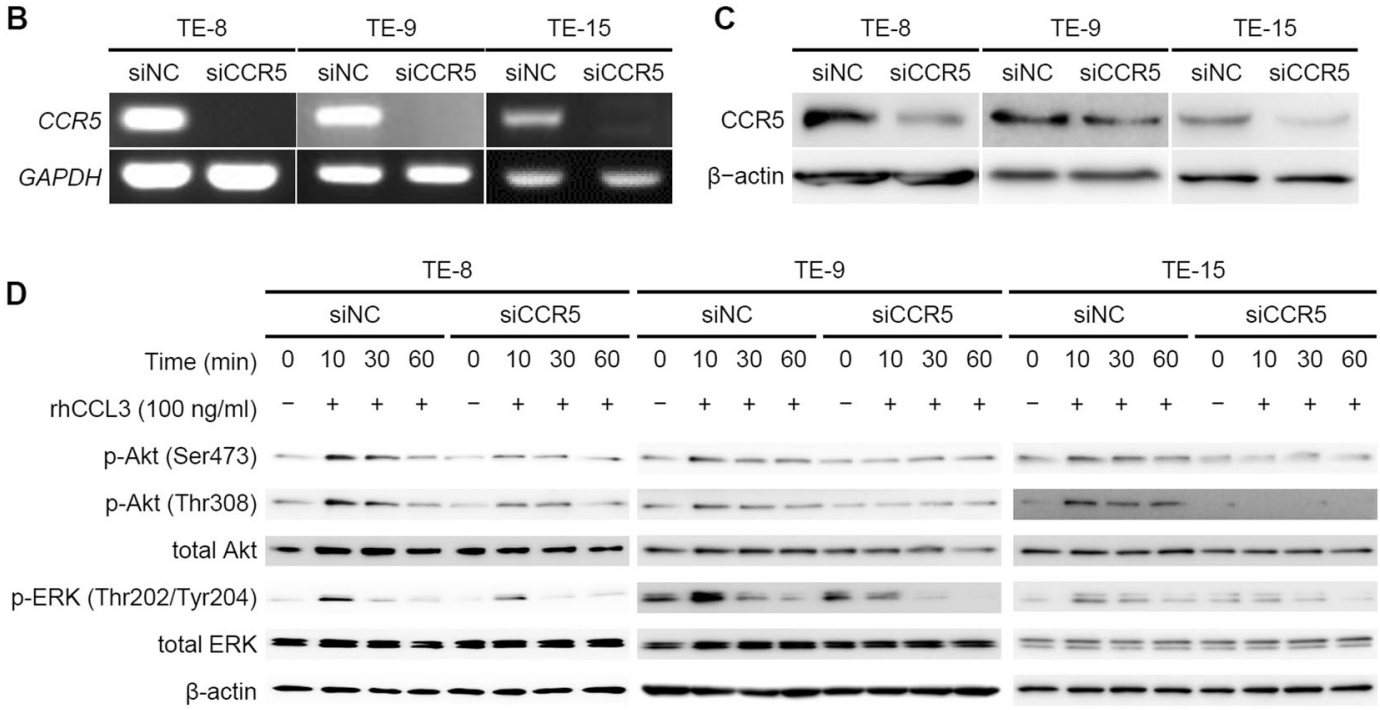

Fig. 3 Signaling pathways in ESCC cell lines treated with rhCCL3. a First, $5 \times 10^{5}$ TE- 8 , TE-9, and TE- 15 cells under serum-free condition were treated with $100 \mathrm{ng} / \mathrm{ml}$ rhCCL3 for 10,30 , and $60 \mathrm{~min}$. Western blotting was conducted with total protein extracted from the ESCC cell lines using antibodies against total Akt, phosphorylated (p-) Akt (Ser473), p-Akt (Thr308), total ERK, p-ERK (Thr202/Tyr204), and $\beta$-actin. Akt and ERK were phosphorylated at $10 \mathrm{~min}$ after rhCCL3 treatment in TE-8, TE-9, and TE-15 cells. The results of densitometric analyses were shown in Fig S1. b-d First, $5 \times 10^{5}$ TE-8,

and TAM15 cells $(5.5 \pm 0.1$-fold, $p<0.001)$ compared with the PBMo-derived macrophages $(1.0 \pm 0.0$-fold) (Fig. 1c). IF detected expression of CCL3 mainly in the cytoplasm of CD204 ${ }^{+}$TAM8, TAM9, and TAM15 cells (Fig. 1d).

\section{The ESCC cell lines expressed CCR5 and CCL3}

We next explored the expression levels of CCR1 and CCR5, which are CCL3 receptors. CCR1 and CCR5 expressions in the TE-8, TE-9, and TE-15 cells were confirmed by RT-PCR (Fig. 2a). Moreover, the western blotting results showed that the expression levels of CCR5 in the TE-8 (6.1 \pm 0.7 -fold, $p=0.004)$, TE-9 (9.5 \pm 1.0 -fold, $p=0.002)$, and TE-15 cells
TE-9, and TE- 15 cells was transfected by $20 \mathrm{nM}$ siRNA against CCR5 (siCCR5) and negative control siRNA (siNC) for 2 days. The CCR5 knockdown of the ESCC cell lines was confirmed by RT-PCR (b) and western blotting using anti-CCR5 (c). Western blotting was conducted with total protein extracted from the ESCC cell lines transfected siCCR5 and siNC (d). The phosphorylations of Akt and ERK stimulated by rhCCL3 was suppressed by transfection with siCCR 5 in TE-8, TE-9, and TE-15 cells. The results of densitometric analyses were shown in Fig S2.
(6.7 \pm 0.6 -fold, $p=0.002)$ were significantly higher than that in the Het-1A cells $(1.0 \pm 0.1$-fold $)$. The expression levels of CCR1 in TE-8 (1.3 \pm 0.1 -fold, $p=0.017)$, TE-9 $(1.4 \pm 0.1$ fold, $p=0.010)$, and TE-15 cells $(1.3 \pm 0.0$-fold, $p=0.008)$ were also significantly higher than that in the Het-1A cells $(1.0 \pm 0.0$-fold $)$, but relatively much lower than the CCR5 expression levels in the three ESCC cell lines (Fig. 2b, c).

The RT-PCR results demonstrated that not only TAMs but also the three ESCC cell lines expressed CCL3 (Fig. 2a). The western blotting results showed that the expression levels of CCL3 in the TE-8 (4.4 \pm 0.2 -fold, $p<$ $0.001)$, TE-9 (5.1 \pm 0.2 -fold, $p<0.001)$, and TE-15 cells $(3.8 \pm 0.1$-fold, $p<0.001)$ were also significantly higher 
Fig. 4 Transwell migration and invasion assays of TE-8 cells. a-e For the migration assay, $2 \times 10^{5}$ TE- 8 cells were plated on the transwell in RPMI1640 medium containing $0.1 \%$ FBS. Then $100 \mathrm{ng} / \mathrm{ml}$ rhCCL3 $(\mathbf{a}-\mathbf{c})$ or $1 \times 10^{5}$ TAM $8(\mathbf{d}, \mathbf{e})$ was added in the lower chamber. The cell inserts were set on 24well plates for $24 \mathrm{~h}$. For the invasion assay, TE-8 cells were plated on the transwell in the same condition, and rhCCL3 $(\mathbf{f}-\mathbf{h})$ or TAM8 (I, J) was added in the lower chamber. The cell inserts were incubated for $48 \mathrm{~h}$. The migrated and invaded cells on the underside of the membrane were stained and counted. Results are mean \pm $\operatorname{SEM}(n=3 ; * p<0.05 ; * * p<$ $0.01 ; * * * p<0.001 ;$ ns not significant). In each assay, the percent migration or invasion was calculated by dividing the number of TE- 8 cells by that in the negative control. a, f $20 \mu \mathrm{M}$ LY294002 and PD98059 were added on the upper chamber, and $0.2 \mu \mathrm{l} / \mathrm{ml}$ DMSO was added as a negative control. $\mathbf{b}, \mathbf{d}, \mathbf{g}, \mathbf{i}$ $20 \mu \mathrm{g} / \mathrm{ml}$ Maraviroc (MVC) was added on the upper chamber, and $0.2 \mu \mathrm{l} / \mathrm{ml}$ DMSO was added as a negative control. c, $\mathbf{h} 2 \times$ $10^{5}$ TE- 8 cells transfected with $20 \mathrm{nM}$ siCCR5 or siNC were plated. e, j $400 \mathrm{ng} / \mathrm{ml} \mathrm{CCL3}$ neutralizing antibody (antiCCL3) was added on the lower chamber, and $400 \mathrm{ng} / \mathrm{ml}$ control $\mathrm{IgG}$ was added as a negative control.
A

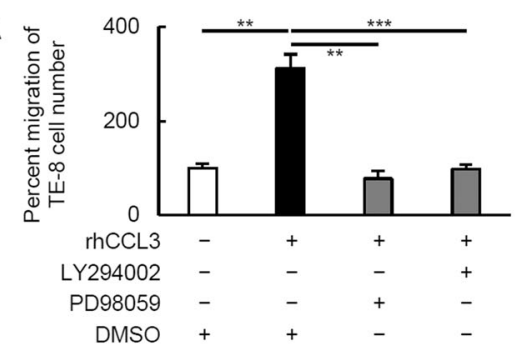

B

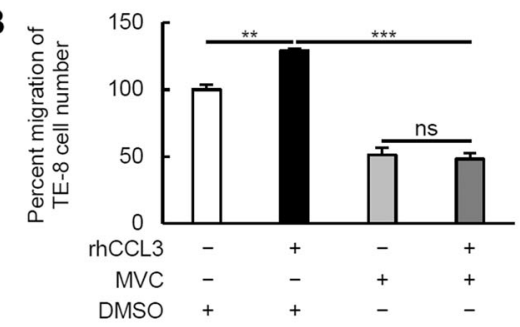

C

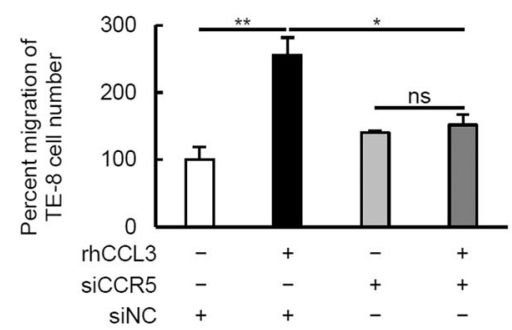

D

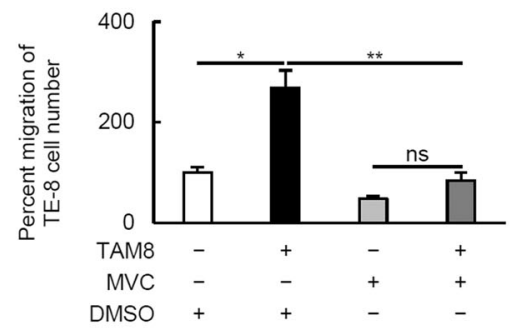

E

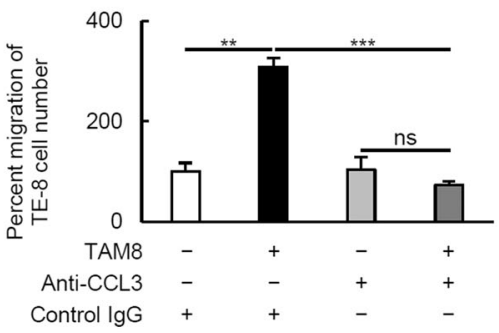

$\mathbf{F}$

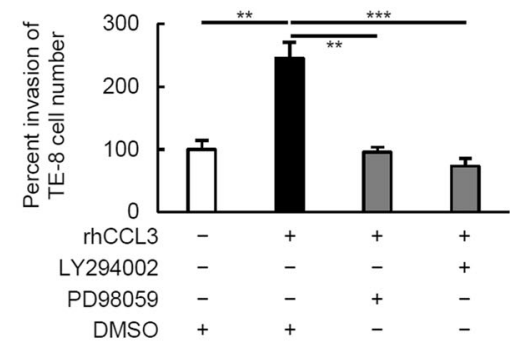

G

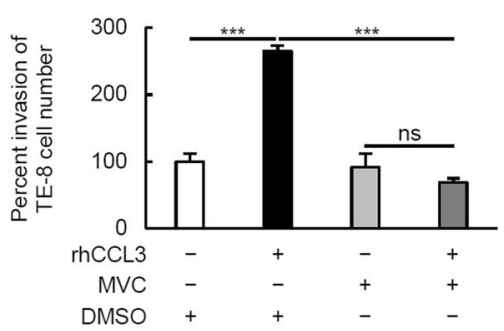

$\mathrm{H}$

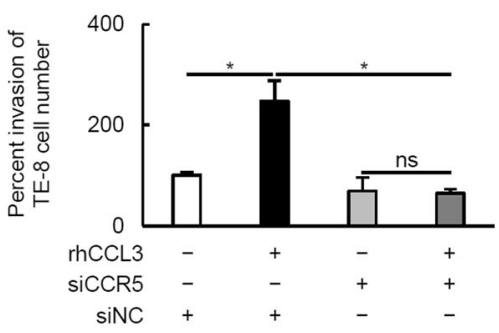

I

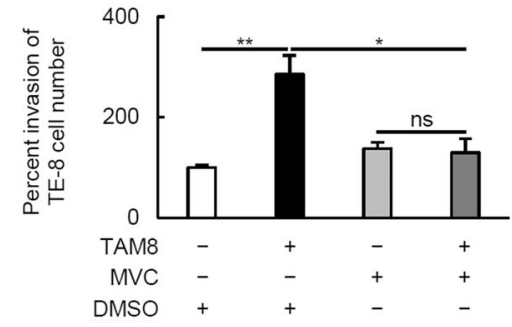

$J$

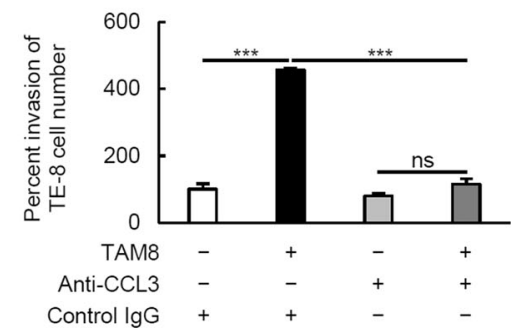

than that in the Het-1A cells $(1.0 \pm 0.0$-fold) (Fig. $2 b, c)$. The ELISA results also confirmed the secretion of CCL3 from the ESCC cell lines (Fig. 2d).

We then performed an IF study using anti-CCR5 or antiCCL3 antibodies on TE-8, TE-9, and TE-15 cells (Fig. 2e). CCR5 expression was detected in the cellular membrane and cytoplasm of TE-8, TE-9, and TE-15 cells, and CCL3 expression was detected in the cytoplasm of TE-8, TE-9, and TE-15 cells.

\section{CCL3 activated Akt and ERK signaling pathways via CCR5 in ESCC cell lines}

We next investigated the effect of CCL3 on the ESCC cell lines. For an exploration of the signaling pathways, we treated TE- 8 , TE-9, and TE-15 cells with $100 \mathrm{ng} / \mathrm{ml}$ of rhCCL3 for 10, 30, and $60 \mathrm{~min}$. We observed the phosphorylations of Akt and ERK at $10 \mathrm{~min}$ after the rhCCL3 treatment in TE-8, TE-9, and TE-15 cells (Figs. 3a, S1). 
We then silenced CCR5 in TE-8, TE-9, and TE-15 cells with the use of siRNA. CCR5 knockdown was confirmed by RT-PCR and western blotting (Figs. 3b, c; S2A). The western blotting revealed that the phosphorylations of $\mathrm{Akt}$ and ERK at 10 min after rhCCL3 treatment were suppressed by the CCR5 knockdown in TE-8, TE-9, and TE-15 (Figs. 3d, S2B). These results suggest a CCL3-CCR5 axis activated Akt and ERK signaling pathways in these ESCC cell lines.

\section{CCL3-CCR5 axis-induced migration and invasion of ESCC cell lines via Akt and ERK signaling pathways}

To explore the roles of the CCL3-CCR5 axis in the ESCC cell lines, we focused on cell migration and invasion. Our findings first revealed that rhCCL3 significantly promoted the migration and invasion of TE- 8 cells, and the migration and invasion were significantly suppressed by the inhibition of PI3K/Akt and MEK/ERK pathways using LY294002 and PD98059, respectively (Fig. 4a, f; representative images are shown in Fig. S4A, B). Maraviroc and CCR5 knockdown were also effective for suppressing the rhCCL3-mediated migration and invasion (Fig. 4b, c, g, h). We then performed the same assays using a co-culture with TAM8 instead of rhCCL3 (Fig. 4d, e, i, j), and observed that TAM8 also significantly promoted the migration and invasion of TE-8 cells, and that the migration and invasion were significantly suppressed by Maraviroc and neutralizing antibody against CCL3. When these assays were performed using TE-9 and TAM9 cells instead of TE- 8 and TAM8 cells, almost the same results was observed (Fig. S3; representative images are shown in Fig. S4C, D).

Next, we investigated whether the CCL3 derived from ESCC cells could promote migration and invasion via CCR5. TE-8 and TE-9 cells were mono-cultured in the upper chamber, and Maraviroc or the neutralizing antibody against CCL3 was added to the lower chamber. The migration of TE-8 cells (Fig. S5A; $100.0 \pm 8.6$ vs. $81.6 \pm$ $7.7 \%, p=0.213$ ), and the invasion of TE-8 (Fig. S5E; $100.0 \pm 34.3$ vs. $83.5 \pm 13.3 \%, p=0.684)$ and TE-9 cells (Fig. S5F; $100.0 \pm 11.1$ vs. $87.8 \pm 5.0 \%, p=0.383$ ) were slightly suppressed by the neutralizing antibody without statistical significance. The migration of TE-9 cells was not suppressed by the neutralizing antibody (Fig. S5B; $100.0 \pm$ 4.3 vs. $101.1 \pm 7.2 \%, p=0.914)$. The migration of TE-9 cells (Fig. S5D; $100.0 \pm 13.8$ vs. $72.7 \pm 6.2 \%, p=0.154$ ), and the invasion of TE-8 (Fig. S5G; $100.0 \pm 17.5$ vs. $73.9 \pm$ $9.0 \%, p=0.289$ ) and TE-9 cells (Fig. S5H; $100.0 \pm 15.7$ vs. $75.2 \pm 9.9 \%, p=0.272$ ) were slightly suppressed by Maraviroc without statistical significance. The migration of TE8 cells was not suppressed by Maraviroc (Fig. S5C; $100.0 \pm$ 3.4 vs. $106.5 \pm 4.7 \%, p=0.367)$. Treatment with rhCCL3 did not show any significant effect on the survival or growth of TE-8, TE-9, and TE-15 cells (Fig. S6). These results suggest that a CCL3-CCR5 axis promotes the migration and invasion of ESCC independently of cell survival and growth.

\section{The CCL3-CCR5 axis upregulated the MMP-2 and VEGF-A expressions in the ESCC cell lines}

After observing that a CCL3-CCR5 axis promoted the migration and invasion of the three ESCC cell lines via PI3K/ Akt and MEK/ERK pathways as described above, we investigated whether CCL3 upregulated the expressions of matrix metalloprotease-2 (MMP-2) and matrix metalloprotease-9 (MMP-9), which are well known to contribute to cell invasion by extracellular matrix remodeling in the tumor microenvironment [6]. We focused on the expression of vascular endothelial growth factor A (VEGF-A) as a surrogate marker of angiogenesis. For the determination of the $M M P 2, M M P 9$, and VEGFA mRNA expression levels, we treated TE-8, TE-9, and TE-15 cells with $100 \mathrm{ng} / \mathrm{ml}$ of rhCCL3 for $48 \mathrm{~h}$. MMP2 mRNA was significantly upregulated in the TE- 8 cells $(1.0 \pm 0.1$ vs. $3.8 \pm 0.0$-fold, $p<0.001)$, TE-9 cells $(1.0 \pm 0.0$ vs. $1.8 \pm 0.1$-fold, $p<0.001)$, and TE-15 cells $(1.0 \pm 0.0$ vs. $1.3 \pm 0.1$-fold, $p=0.017)$ at $48 \mathrm{~h}$ after rhCCL3 treatment (Fig. 5a). $M M P 9$ mRNA was significantly upregulated in the TE-15 cells $(1.0 \pm 0.0$ vs. $1.4 \pm 0.0$-fold, $p=0.002)$, but not in TE- 8 cells $(1.0 \pm 0.1$ vs. $1.0 \pm 0.2$-fold, $p=0.911)$ or TE-9 cells $(1.0 \pm 0.0$ vs. $1.1 \pm 0.0$-fold, $p=$ 0.263) (Fig. 5b). VEGFA mRNA was significantly upregulated in TE-9 cells $(1.0 \pm 0.0$ vs. $1.7 \pm 0.1$-fold, $p<0.001)$ and TE- 15 cells $(1.0 \pm 0.0$ vs. $1.5 \pm 0.1$-fold, $p=0.001)$, but not in TE-8 cells $(1.0 \pm 0.0$ vs. $1.0 \pm 0.0$-fold, $p=0.089)$ (Fig. $5 c$ ). Next, we investigated the $M M P 2, M M P 9$, and VEGFA mRNA expression levels after LY294002 or PD98059 treatment. TE-8 and TE-15 cells were treated with $100 \mathrm{ng} / \mathrm{ml}$ of rhCCL3 and $20 \mu \mathrm{M}$ of LY294002 or PD98059 for the first 24 $\mathrm{h}$, then they were treated with only rhCCL3 for the next $24 \mathrm{~h}$. TE-9 cells were treated with $100 \mathrm{ng} / \mathrm{ml}$ of rhCCL3 and $20 \mu \mathrm{M}$ of LY294002 or PD98059 for $48 \mathrm{~h}$. The upregulated mRNA expression of MMP2 and VEGFA was suppressed by both LY294002 and PD98059 treatment (Fig. S7A, C). In contrast, the $M M P 9$ mRNA expression in TE-15 was upregulated by LY294002 or PD98059 with rhCCL3 treatment (Fig. S7B). Thus, the treatment with rhCCL3 upregulated the expressions of MMP-2 and VEGF-A in multiple ESCC cell lines via PI3K/Akt and MEK/ERK pathways.

\section{CCL3 and/or CCR5 expression in human ESCC tissues is correlated with poor patient prognosis}

Lastly, we investigated the expressions of CCL3 and CCR5 in the human ESCC tissues, and we determined the correlations between these expressions and each of several 
A

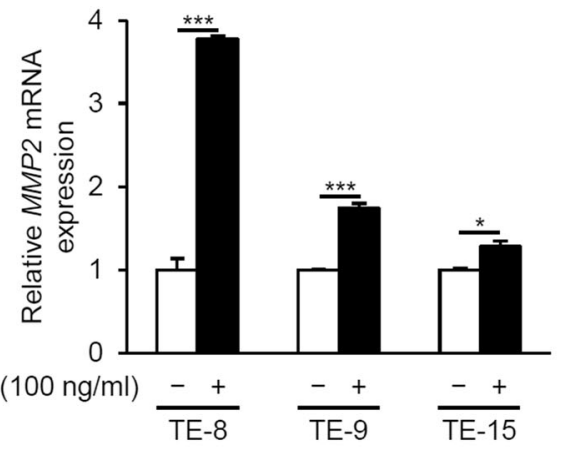

B

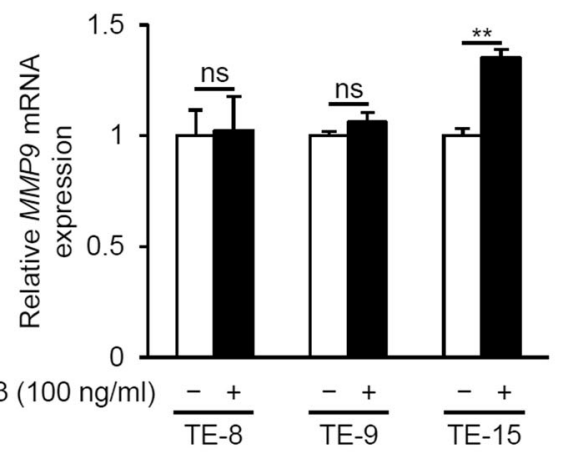

C

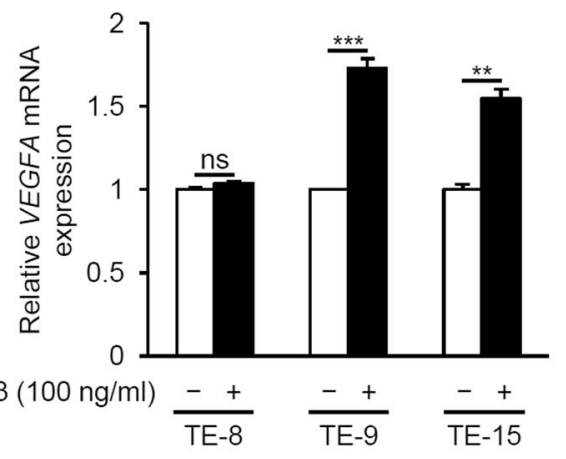

Fig. 5 The expressions of matrix metalloproteases and an angiogenic factor VEGF-A in the ESCC cell lines treated with rhCCL3. First, $5 \times 10^{5}$ TE- 8 , TE-9, or TE-15 cells under serum-free conditions were treated with $100 \mathrm{ng} / \mathrm{ml}$ rhCCL3 for $48 \mathrm{~h}$. a $M M P 2$, b $M M P 9$, and c VEGFA mRNA expression levels of the ESCC cell lines were determined by quantitative RT-PCR and normalized to GAPDH expression. Data are mean $\pm \operatorname{SEM}(n=3, * p<0.05 ; * * p<0.01 ; * * * p$ $<0.001$; ns not significant).

clinicopathological factors and patient prognosis by immunohistochemistry. Both CCL3 and CCR5 immunoreactivities were detected diffusely in the tumor nests. The CCL3 and CCR5 expression levels in the tumor nests were assessed and divided into low and high groups based on the staining intensity (Fig. 6a, b). Double IF of CCL3 and CD204 confirmed that CCL3 was expressed both by TAMs and cancer cells (Fig. 6c).

A high expression of CCL3 did not significantly correlate with any of the clinicopathological factors, whereas a high expression of CCR5 was significantly correlated with deeper invasion $(p=0.016)$, presence of vascular invasion $(p=0.029)$, higher pathological stage $(p=0.041)$, higher numbers of infiltrating CD204 ${ }^{+}$TAMs $(p=0.006)$, and higher microvascular density $(p=0.006)$. Because we detected a significant correlation between a high expression of CCL3 and CCR5 $(p=0.010)$, we divided the patients into two groups: the patients with high expressions of both CCL3 and CCR5 (H/H group, $n=35$ ), and the other patients (non- $\mathrm{H} / \mathrm{H}$ group, $n=33$ ). The $\mathrm{H} / \mathrm{H}$ group was significantly correlated with higher pathological stage $(p=$ 0.044) (Table 1).

A high expression of CCL3 was significantly correlated with the patients' cause-specific survival $(p=0.041)$ (Fig. 7a), but not with the overall survival or disease-free survival ( $p=0.951$ and 0.101 , respectively). In contrast, a high expression of CCR5 was significantly correlated with disease-free survival and cause-specific survival $(p=0.043$ and 0.047 , respectively), but not with overall survival ( $p=$ 0.089) (Fig. 7b). A high expression of both CCL3 and CCR5 was significantly correlated with not only diseasefree survival and cause-specific survival $(p=0.018$ and 0.007 , respectively), but also with the overall survival ( $p=$ 0.067) (Fig. 7c). A significant independent impact of a high expression of both CCL3 and CCR5 on the disease-free survival rate in ESCC was not detected by the multivariate analysis $(p=0.071)$ (Table 2).

\section{Discussion}

CCL3 is involved in the progression of various malignancies via CCR1 and/or CCR5 as mentioned above. In most of these above-cited studies, it was described that CCL3 was expressed in neoplastic cells [17, 18, 20, 21, 2327]. CCL3 expression in nonneoplastic stromal and/or inflammatory cells in the tumor microenvironment was also described in some of those studies [17, 20-22, 24-27]. However, only a few reports investigated the significance of CCL3 derived from inflammatory cells in a tumor microenvironment: CCL3 derived from basophils contributes to the maintenance of leukemia-initiating cells in chronic myeloid leukemia [25], and CCL3 derived from macrophages and granulocytes contributes to the accumulation of $\mathrm{CCR}^{+}$fibroblasts in murine colitis-associated cancer [22] In the present study, CCL3 expression was detected in both neoplastic cells and TAMs in vitro as well as in human ESCC tissues. The present study is the first to focus on the role of CCL3 derived from both TAMs and neoplastic cells in the progression of human ESCC. However, the secretion level of CCL3 from TAM-like macrophages was much higher than those from ESCC cell lines. These observations suggest that TAMs are one of the most important sources of 
A

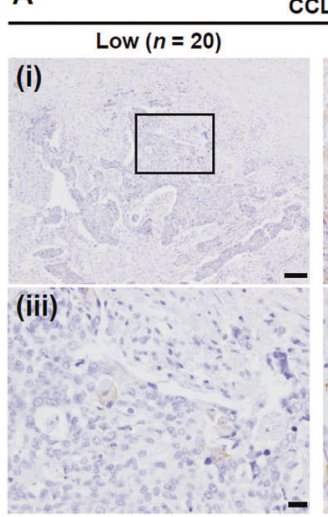

$\mathrm{CCL} 3$

(ii)

High $(n=48)$

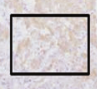

(iv)

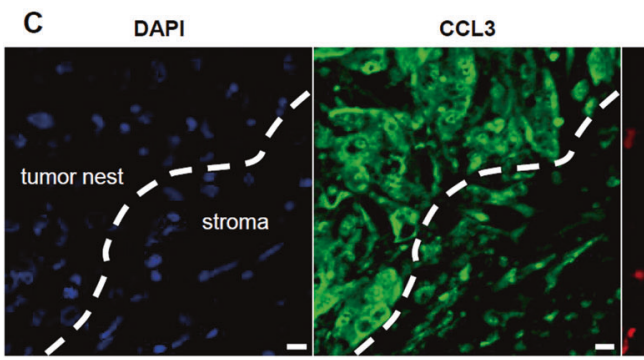

B

$\operatorname{Low}(n=25) \quad \operatorname{High}(n=43)$

(i)
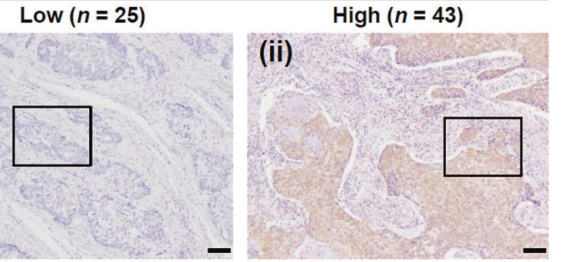
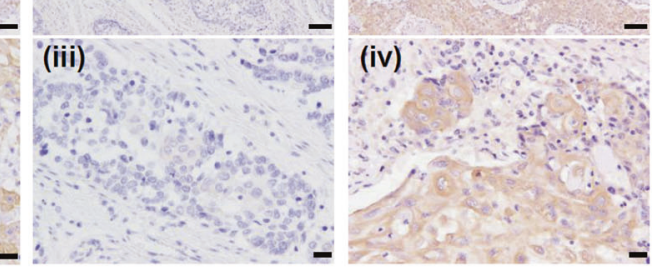

CD204

CD204

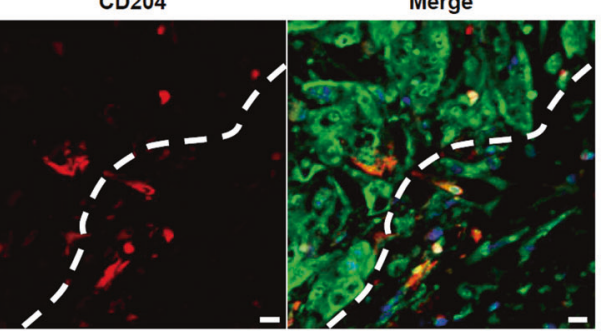

Fig. 6 The expression of CCL3 and CCR5 in the human ESCC tissue samples. a Representative CCL3 immunoreactivities in human ESCC tissues. The immunoreactivity in the tumor nests was assessed and divided into low $(n=20)$ and high $(n=48)$ groups based on the staining intensity. Typical images are shown: low expression (i, iii) and high expression (ii, iv). Areas delimited by squares in (i) and (ii) (magnification: $\times 100$; scale bar: $100 \mu \mathrm{m}$ ) are showed in higher magnification in (iii) and (iv) (magnification: $\times 400$; scale bar: $20 \mu \mathrm{m}$ ), respectively. b Representative CCR5 immunoreactivities in human ESCC tissues. Immunoreactivity in the tumor nest was assessed and

CCL3 in human ESCC microenvironment. However, it still remains unknown how conditioned media of ESCC cell lines induce the CCL3 expression in TAM-like macrophages. It has been reported that HIV infection, lipopolysaccharide, and IL-1 $\beta$ induce CCL3 secretion from macrophages [16]. Chen et al. reported that IL-1 $\beta$ was expressed in human ESCC cell [47]. IL-1 $\beta$ was also expressed in M2 TAMs in human ESCC [13, 48]. We suggest that IL-1 $\beta$ derived from ESCC cells and/or TAMs may induce CCL3 secretion from TAMs; however the role of IL-1 $\beta$ against TAMs in ESCC was not well understood.

In the present study, three ESCC cell lines express CCR5 much higher (6.1-9.5-folds) than Het-1A cells, a normal human esophageal squamous epithelial cell line. In contrast, CCR1 expression levels in ESCC cell lines against Het-1A cells were relatively much lower (1.3-1.4-folds) than the CCR5 expression levels. Thus, we focused on the roles of CCL3-CCR5 axis in ESCC. The results of the present study suggested that PI3K/Akt and MEK/ERK pathways were activated downstream of the CCL3-CCR5 axis in ESCC cells. It is well known that Akt and ERK are phosphorylated divided into low $(n=25)$ and high $(n=43)$ groups based on the staining intensity. Typical images are shown: low expression (i, iii) and high expression (ii, iv). Areas delimited by squares in (i) and (ii) (magnification: $\times 100$; scale bar: $100 \mu \mathrm{m}$ ) are showed in higher magnification in (iii) and (iv) (magnification: $\times 400$; Scale bar: $20 \mu \mathrm{m}$ ), respectively. c Double immunofluorescence was performed using antibodies against CCL3 (green) and CD204 (red). CCL3 was expressed in both cancer cells and CD204 ${ }^{+}$TAMs. Nuclei were stained by DAPI (blue). White dotted line indicates the edge of the tumor nest. Magnification: $\times 400$. Scale bar: $10 \mu \mathrm{m}$.

downstream of the CCL3-CCR5 axis [19, 28, 49]. In addition, there are two sub-pathways in PI3K/Akt, PDK1, and mTORC2. PDK1 phosphorylates Akt on Thr308, whereas mTORC2 phosphorylates Akt on Ser473 [50-52]. In all three ESCC cell lines, rhCCL3 treatment significantly upregulated both p-Akt (Ser473) and p-Akt (Thr308) via CCR5. These observations suggest that the CCL3-CCR5 axis activates Akt via both sub-pathways, PDK1 and mTORC2, in ESCC cells. However, it remains the problem of whether PDK1 or mTORC2 is predominantly activated in each ESCC cell line.

PI3K/Akt and MEK/ERK pathways are activated by many cellular stimuli, and these pathways play key roles in cell regulation including cell growth, survival, migration, invasion, stemness, and metabolism, and they contribute to tumor progression [53, 54]. We observed herein that a CCL3-CCR5 axis promoted the migration and invasion of the three ESCC cell lines via PI3K/Akt and MEK/ERK pathways. Past studies revealed that PI3K/Akt and/or MEK/ ERK pathways were also involved in the migration and invasion of ESCC cells in vitro [13-15, 55-57]. 
Table 1 Correlations between CCL3 and/or CCR5 expression and clinicopathological factors.

\begin{tabular}{|c|c|c|c|c|c|c|c|c|c|c|}
\hline & \multirow[t]{2}{*}{$n$} & \multicolumn{3}{|c|}{ CCL3 expression } & \multicolumn{3}{|c|}{ CCR5 expression } & \multicolumn{3}{|c|}{ CCL3 and CCR5 expression } \\
\hline & & $\begin{array}{l}\text { Low } \\
(n=20)\end{array}$ & $\begin{array}{l}\text { High } \\
(n=48)\end{array}$ & $p$ value & $\begin{array}{l}\text { Low } \\
(n=25)\end{array}$ & $\begin{array}{l}\text { High } \\
(n=43)\end{array}$ & $p$ value & $\begin{array}{l}\text { Non-H/H } \\
(n=33)\end{array}$ & $\begin{array}{l}\mathrm{H} / \mathrm{H} \\
(n=35)\end{array}$ & $p$ value \\
\hline \multicolumn{11}{|l|}{ Age } \\
\hline$<65$ & 32 & 10 & 22 & 0.754 & 12 & 20 & 0.906 & 15 & 17 & 0.977 \\
\hline$\geq 65$ & 36 & 10 & 26 & & 13 & 23 & & 17 & 19 & \\
\hline \multicolumn{11}{|l|}{ Sex } \\
\hline Female & 14 & 4 & 10 & 0.938 & 6 & 8 & 0.596 & 9 & 5 & 0.147 \\
\hline Male & 54 & 16 & 38 & & 19 & 35 & & 23 & 31 & \\
\hline \multicolumn{11}{|c|}{ Histological grade ${ }^{\mathrm{a}}$} \\
\hline $\mathrm{IS}+\mathrm{WD}$ & 15 & 5 & 10 & 0.706 & 5 & 10 & 0.755 & 7 & 8 & 0.973 \\
\hline $\mathrm{MD}+\mathrm{PD}$ & 53 & 15 & 38 & & 20 & 33 & & 25 & 28 & \\
\hline \multicolumn{11}{|c|}{ Depth of invasion ${ }^{\mathrm{b}}$} \\
\hline Tis $+\mathrm{T} 1$ & 48 & 15 & 33 & 0.606 & 22 & 26 & $0.016^{*}$ & 26 & 22 & 0.069 \\
\hline $\mathrm{T} 2+\mathrm{T} 3$ & 20 & 5 & 15 & & 3 & 17 & & 6 & 14 & \\
\hline \multicolumn{11}{|c|}{ Lymphatic invasion } \\
\hline Negative & 37 & 12 & 25 & 0.550 & 17 & 20 & 0.086 & 19 & 18 & 0.438 \\
\hline Positive & 31 & 8 & 23 & & 8 & 23 & & 13 & 18 & \\
\hline \multicolumn{11}{|c|}{ Vascular invasion } \\
\hline Negative & 43 & 12 & 31 & 0.721 & 20 & 23 & $0.029 *$ & 22 & 21 & 0.374 \\
\hline Positive & 25 & 8 & 17 & & 5 & 20 & & 10 & 15 & \\
\hline \multicolumn{11}{|c|}{ Lymph node metastasis } \\
\hline Negative & 43 & 16 & 27 & 0.064 & 19 & 24 & 0.096 & 24 & 19 & 0.058 \\
\hline Positive & 25 & 4 & 21 & & 6 & 19 & & 8 & 17 & \\
\hline \multicolumn{11}{|c|}{ Pathological stage ${ }^{\mathrm{b}}$} \\
\hline $0+\mathrm{I}$ & 38 & 14 & 24 & 0.130 & 18 & 20 & $0.041 *$ & 22 & 16 & $0.044 *$ \\
\hline $\mathrm{II}+\mathrm{III}+\mathrm{IV}$ & 30 & 6 & 24 & & 7 & 23 & & 10 & 20 & \\
\hline \multicolumn{11}{|l|}{$\mathrm{CD} 8^{+}$cells $^{\mathrm{c}}$} \\
\hline Low & 35 & 10 & 25 & 0.876 & 13 & 22 & 0.947 & 15 & 20 & 0.475 \\
\hline High & 33 & 10 & 23 & & 12 & 21 & & 17 & 16 & \\
\hline \multicolumn{11}{|l|}{$\mathrm{CD}_{163^{+}}$cells $^{\mathrm{c}}$} \\
\hline Low & 34 & 9 & 25 & 0.595 & 15 & 19 & 0.209 & 17 & 17 & 0.627 \\
\hline High & 34 & 11 & 23 & & 10 & 22 & & 15 & 19 & \\
\hline \multicolumn{11}{|l|}{$\mathrm{CD}_{204^{+}}$cells $^{\mathrm{c}}$} \\
\hline Low & 34 & 11 & 23 & 0.595 & 18 & 16 & $0.006 * *$ & 19 & 15 & 0.145 \\
\hline High & 34 & 9 & 25 & & 7 & 27 & & 13 & 21 & \\
\hline \multicolumn{11}{|c|}{ Microvascular density ${ }^{\mathrm{d}}$} \\
\hline Low & 34 & 11 & 23 & 0.595 & 18 & 16 & $0.006 * *$ & 18 & 16 & 0.331 \\
\hline High & 34 & 9 & 25 & & 7 & 27 & & 14 & 20 & \\
\hline \multicolumn{11}{|c|}{ CCR5 expression } \\
\hline Low & 25 & 12 & 13 & $0.010^{*}$ & & & & & & \\
\hline High & 43 & 8 & 35 & & & & & & & \\
\hline
\end{tabular}

Data were analyzed by $\chi^{2}$-test.

$* p<0.05, * * p<0.01$.

${ }^{a}$ According to the 11th edition of Japanese Classification of Esophageal Cancer: IS squamous cell carcinoma (SCC) in situ/high grade intraepithelial neoplasia, $W D$ well differentiated SCC, $M D$ moderately differentiated SCC, $P D$ poorly differentiated SCC [44, 45].

${ }^{\mathrm{b}}$ According to the 8th edition of the TNM classification: Tis carcinoma in situ/high grade dysplasia, $T 1$ tumor invades lamina propria, muscularis mucosae or submucosa, $T 2$ tumor invades muscularis propria, $T 3$ tumor invades adventitia [46].

${ }^{c}$ The patients were divided into low and high groups based on the median number of infiltrating $\mathrm{CD}^{+} 8^{+}, \mathrm{CD}_{163}{ }^{+}$, or $\mathrm{CD}^{204} 4^{+}$macrophage in tumor cell nests and the tumor stroma [12].

${ }^{\mathrm{d}}$ The patients were divided into low and high groups based on the median microvascular density [12].

CCL3-CCR5 axis-promoted migration and invasion were also reported in oral squamous cell carcinoma [27] and 

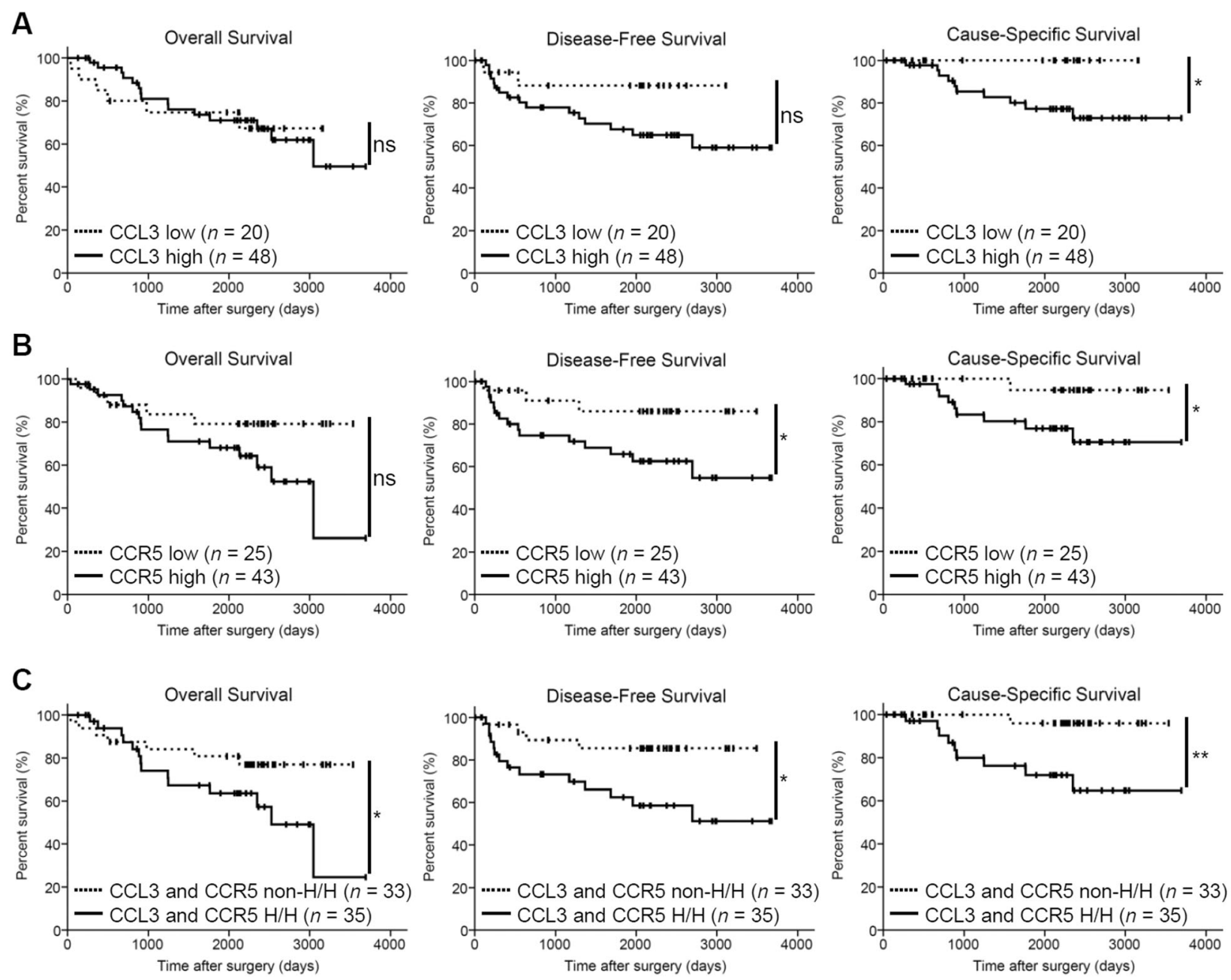

Fig. 7 Kaplan-Meier analyses of the overall survival, disease-free survival, and cancer-related survival of ESCC patients. The patients were divided into low and high CCL3 expression groups (a); low and high CCR5 expression groups (b); high expression of both

chondrosarcoma [21]. Our present findings are consistent with those of past studies of the CCL3-CCR5 axis and the $\mathrm{PI} 3 \mathrm{~K} / \mathrm{Akt}$ and/or MEK/ERK pathway-derived migration and invasion of neoplastic cells. In the present assay, treatment with Maraviroc or the neutralizing antibody against CCL3 suppressed significantly cell migration and invasion when the ESCC cell lines were co-cultured with TAMs, and suppressed them slightly, but not significantly, when ESCC cell lines were mono-cultured without rhCCL3 treatment. We thus speculate that the CCL3-CCR5 axis plays key role in the progression of ESCC when neoplastic cells are interacting with TAMs. The quantity and the roles that the ESCC cell-derived CCL3 plays in their microenvironment may be limited.

MMP-2 and MMP-9 remodel extracellular matrix and contribute to cell invasion, and VEGF-A promotes angiogenesis in various malignancies [6]. In ESCC, MMP-2 and MMP-9 contribute to tumor invasion and metastasis
CCL3 and CCR5 $(\mathrm{H} / \mathrm{H})$ and all the other patients (non-H/H) groups (c). The data were analyzed by log-rank test $(* p<0.05 ; * * p<0.01$; ns not significant).

[58, 59], and VEGFs including VEGF-A contribute to angiogenesis and are associated with high microvascular density and poor patient prognosis [60-62]. MMP-2 is involved in CCL3-dependent cell invasion in oral squamous cell carcinoma [27] and chondrosarcoma [21], whereas MMP-9 is involved in CCL3-dependent cell invasion in hepatocellular carcinoma [17] and oral squamous cell carcinoma [27]. VEGF-A is involved in CCL3-dependent angiogenesis in osteosarcoma [23] and is also upregulated downstream of the CCL3-CCR5 axis in oral squamous cell carcinoma [27]. Activating the PI3K/Akt and MEK/ERK pathways induces the expressions of MMP-2, MMP-9, and VEGF-A in various malignancies including ESCC [62-65]. Our present results demonstrated that treatment with rhCCL3 upregulated the $M M P 2$ mRNA expression in three ESCC cell lines universally, and the VEGFA mRNA expression in two ESCC cell lines. All upregulated expressions of $M M P 2$ and $V E G F A$ after rhCCL3 treatment 
Table 2 Univariate and multivariate Cox regression analysis of prognostic factors for disease-free survival.

\begin{tabular}{|c|c|c|c|c|c|c|}
\hline & \multirow[t]{2}{*}{$n$} & \multicolumn{3}{|l|}{ Univariate analysis } & \multicolumn{2}{|c|}{ Multivariate analysis } \\
\hline & & Mean survival (years) & HR $(95 \% \mathrm{CI})$ & $p$ value & HR $(95 \% \mathrm{CI})$ & $p$ value \\
\hline \multicolumn{7}{|l|}{ Age } \\
\hline$<65$ & 32 & 7.07 & 0.654 & 0.375 & & \\
\hline$\geq 65$ & 36 & 7.91 & $(0.252-1.691)$ & & & \\
\hline \multicolumn{7}{|l|}{ Sex } \\
\hline Female & 14 & 8.65 & 2.417 & 0.189 & & \\
\hline Male & 54 & 7.28 & $(0.555-10.529)$ & & & \\
\hline \multicolumn{7}{|c|}{ Histological grade $\mathrm{a}^{\mathrm{a}}$} \\
\hline $\mathrm{IS}+\mathrm{WD}$ & 15 & 5.81 & 1.560 & 0.485 & & \\
\hline $\mathrm{MD}+\mathrm{PD}$ & 53 & 7.42 & $(0.448-5.431)$ & & & \\
\hline \multicolumn{7}{|c|}{ Depth of invasion ${ }^{\mathrm{b}}$} \\
\hline Tis $+\mathrm{T} 1$ & 48 & 9.09 & 12.450 & $<0.001 * * *$ & 8.580 & $0.005 * *$ \\
\hline $\mathrm{T} 2+\mathrm{T} 3$ & 20 & 3.59 & $(4.373-35.450)$ & & $(1.933-38.074)$ & \\
\hline \multicolumn{7}{|c|}{ Lymphatic invasion } \\
\hline Negative & 37 & 8.91 & 4.961 & $0.003^{* *}$ & 0.757 & 0.731 \\
\hline Positive & 31 & 5.84 & $(1.745-14.106)$ & & $(0.155-3.698)$ & \\
\hline \multicolumn{7}{|c|}{ Vascular invasion } \\
\hline Negative & 43 & 8.33 & 2.706 & $0.038^{*}$ & 1.685 & 0.366 \\
\hline Positive & 25 & 4.84 & $(1.059-6.917)$ & & $(0.544-5.223)$ & \\
\hline \multicolumn{7}{|c|}{ Lymph node metastasis } \\
\hline Negative & 43 & 9.28 & 8.375 & $<0.001 * * *$ & 3.388 & 0.064 \\
\hline Positive & 25 & 4.42 & $(2.745-25.552)$ & & $(0.932-12.322)$ & \\
\hline \multicolumn{7}{|c|}{ Pathological stage ${ }^{\mathrm{b}}$} \\
\hline $0+\mathrm{I}$ & 38 & 9.47 & 9.544 & $<0.001^{* *}$ & & \\
\hline $\mathrm{II}+\mathrm{III}+\mathrm{IV}$ & 30 & 4.69 & $(2.749-33.133)$ & & & \\
\hline \multicolumn{7}{|c|}{ CCL3 expression } \\
\hline Low & 20 & 7.62 & 3.206 & 0.121 & & \\
\hline High & 48 & 7.10 & $(0.736-13.969)$ & & & \\
\hline \multicolumn{7}{|c|}{ CCR5 expression } \\
\hline Low & 25 & 8.50 & 3.337 & 0.057 & & \\
\hline High & 43 & 6.82 & $(0.965-11.539)$ & & & \\
\hline \multicolumn{7}{|c|}{ CCL3 and CCR5 expression } \\
\hline Non-H/H & 33 & 8.44 & 3.534 & $0.026^{*}$ & 3.136 & 0.071 \\
\hline $\mathrm{H} / \mathrm{H}$ & 35 & 6.53 & $(1.160-10.765)$ & & $(0.906-10.856)$ & \\
\hline \multicolumn{7}{|l|}{$\mathrm{CD} 8^{+}$cells $^{\mathrm{c}}$} \\
\hline Low & 35 & 8.78 & 3.638 & $0.009^{* *}$ & & \\
\hline High & 33 & 6.05 & $(1.293-10.233)$ & & & \\
\hline \multicolumn{7}{|l|}{$\mathrm{CD}_{163^{+}}$cells $^{\mathrm{c}}$} \\
\hline Low & 34 & 8.54 & 2.591 & 0.058 & & \\
\hline High & 34 & 6.62 & $(0.969-6.924)$ & & & \\
\hline \multicolumn{7}{|l|}{$\mathrm{CD} 204^{+}$cells $^{\mathrm{c}}$} \\
\hline Low & 34 & 8.96 & 4.755 & $0.006^{* *}$ & 1.176 & 0.799 \\
\hline High & 34 & 6.04 & $(1.564-14.461)$ & & $(0.337-4.112)$ & \\
\hline \multicolumn{7}{|c|}{ Microvascular density $^{\mathrm{d}}$} \\
\hline Low & 34 & 7.35 & 0.832 & 0.698 & & \\
\hline High & 34 & 7.86 & $(0.328-2.111)$ & & & \\
\hline
\end{tabular}

Data were analyzed by Cox regression analysis. Data were analyzed by $\chi^{2}$-test.

$* p<0.05, * * p<0.01, * * * p<0.001$.

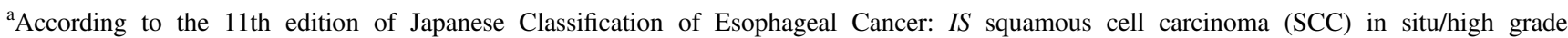
intraepithelial neoplasia, $W D$ well differentiated SCC, $M D$ moderately differentiated SCC, $P D$ poorly differentiated SCC [44, 45].

${ }^{\mathrm{b}}$ According to the 8th edition of the TNM classification: Tis carcinoma in situ/high grade dysplasia, $T 1$ tumor invades lamina propria, muscularis mucosae, or submucosa, $T 2$ tumor invades muscularis propria, $T 3$ tumor invades adventitia [46].

${ }^{\mathrm{c}}$ The patients were divided into low and high groups based on the median number of infiltrating CD68 ${ }^{+}, \mathrm{CD} 163^{+}$, or $\mathrm{CD} 204^{+}$macrophage in tumor cell nests and the tumor stroma [12].

${ }^{\mathrm{d}}$ The patients were divided into low and high groups based on the median microvascular density [12]. 
were suppressed by LY294002 and PD98059. We thus speculate that in ESCC, MMP-2 is involved in the CCL3-CCR5 axis-derived cell invasion via PI3K/Akt and MEK/ERK pathways, and VEGF-A contributes to angiogenesis via the CCL3-CCR5 axis and PI3K/Akt and MEK/ ERK pathways.

In contrast, rhCCL3 treatment upregulated the MMP9 mRNA expression only in TE-15 cells, and paradoxically, the upregulated expression of MMP9 by rhCCL3 was further upregulated by LY294002 and PD98059. CCL3dependent $M M P 9$ upregulation in ESCC cells may be not universal, and may occur via other signaling pathways, such as p38 MAPK, AMPK, or NF- $\mathrm{kB}$, which were also reported to be activated downstream of CCL3-CCR5 axis [21, 49]. The paradoxical MMP9 upregulation by LY294002 and PD98059 with rhCCL3 may be caused by the compensatory upregulation of other pathways due to Akt and ERK inhibition.

However, there still remains the problem why the $M M P 9$ and VEGFA upregulations differ between each cell line. No association between upregulations and poor differentiation was evident. Past studies showed that there was no association between MMP9 or VEGFA expression, and the histological grade in ESCC [58, 60]. Our clinical data showed that CCL3 and/or CCR5 expression did not associate with histological grade. Differences between the $M M P 9$ and VEGFA upregulations do not seem to rely on the differentiation of ESCC cell lines. These differences may occur by the different genetic background, however the genetics of TE series ESCC cell lines were not revealed in full [43].

Herein, we detected immunoreactivities for both CCL3 and CCR5 in the tumor nests of human ESCC tissues. These observations are consistent with those of immunohistochemical and immunofluorescent examinations of CCL3 and CCR5 in human or murine cancer tissues $[17,20,21,23,26,27,32,34-36]$. Our examination of double IF showed that CCL3 was expressed in both neoplastic cells and TAMs in the tumor nest of human ESCC tissue. In the present immunohistochemical assay, it was difficult to distinguish the CCL3 expression in neoplastic cells or nonneoplastic inflammatory cells, because of its diffuse and uniform staining pattern. However, the secretion level of CCL3 in the three ESCC cell lines was much lower than that in PBMo-derived TAM-like macrophages. This discrepancy suggested that the results of the past and present immunohistochemical studies of CCL3 might not adequately reflect the CCL3 secretion levels in tissue.

We observed that high CCL3 expression in the human ESCC tissue samples was significantly associated with poor cause-specific survival but not with disease-free survival, overall survival, or any of the clinicopathological factors. In contrast, high CCR5 expression in the human ESCC tissue samples was significantly associated with poorer diseasefree and cause-specific survival, deeper invasion, vascular invasion, higher pathological stage, higher numbers of infiltrating CD204 ${ }^{+}$TAMs, and higher microvascular density. A high expression of CCR5 was more closely associated with poor prognosis and clinicopathological factors compared with a high expression of CCL3. This may be explained by the following: (1) These are other CCR5 ligands, e.g., CCL4, CCL5, CCL8, and CCL3L1 [29, 30]. We have demonstrated that CCL4, CCL5, and CCL8 are also upregulated in TAM8, TAM9, and TAM15 cells [13]. The CCL4-CCR5, CCL5-CCR5, and CCL8-CCR5 axes appear to be involved in the progression of ESCC. (2) As mentioned above, we suggest that CCL3 immunohistochemistry may not preciously reflect the CCL3 secretion levels in tissue, especially in neoplastic cells. The clinicopathological association between high CCR5 expression and deeper invasion supports the findings of promoted cell invasion and upregulated MMP2 mRNA expression in the three ESCC cell lines by rhCCL3 treatment. In addition, the clinicopathological association between high CCR5 expression and presence of vascular invasion or higher microvascular density supports our observation of upregulated VEGFA mRNA expression in the ESCC cell lines following the rhCCL3 treatment.

There are a few reports which have found that high levels of CCL3 and/or CCR5 expressions in human cancer tissue were associated with poor prognosis. In oral squamous cell carcinoma, the mean survival rate for patients with high numbers of CCL3-positive cells in the tumor parenchyma was shorter than that of the patients with low numbers of CCL3-positive cells, although not significantly [26]. A high plasma level of CCL3 was associated with poor survival rate in chronic lymphocytic leukemia [66] and diffuse-large B-cell lymphoma [67]. CCR5 was reported to be associated with poor overall survival in breast cancer [34], poor relapse-free survival in prostate cancer [68], high histological grade in pancreatic cancer [35], and perineural invasion in salivary adenoid cystic carcinoma [36]. The present study is the first report which revealed that the expression of both CCL3 and CCR5 in human cancer tissue is associated with poor patient prognosis.

Moreover, high expression of both CCL3 and CCR5 in the human ESCC tissue was significantly associated with poor overall, disease-free and cause-specific survivals. However, it could not show a significant independent impact on the disease-free survival rate, the $p$ value $(0.071)$ was very close to the significance cut-off $(0.05)$. A CCL3-CCR5 axis may therefore play a key role in the tumor progression, and it could be the target of new therapies against ESCC. In this study, the CCR5 antagonist, Maraviroc, inhibited the CCL3-CCR5 axis-dependent ESCC migration and invasion. Maraviroc is used 


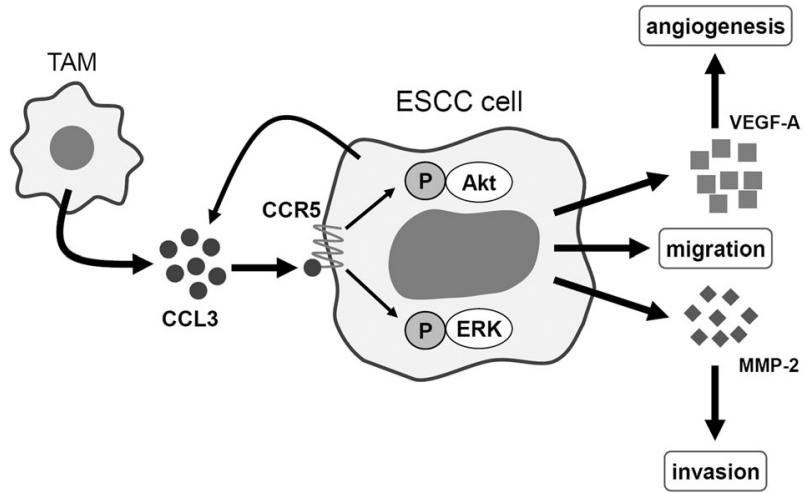

Fig. 8 Schematic model of the CCL3-CCR5 axis in esophageal squamous cell carcinoma. CCL3 is derived from both TAMs and cancer cells and is bound to CCR5 on cancer cells. CCL3-CCR5 interaction contributes to the progression of ESCC by activating Akt and ERK signaling pathways and by promoting the migration and invasion of cancer cells and angiogenesis.

clinically as an anti-HIV agent and has shown few side effects, and it was reported to reduce lung metastasis and inhibit the tumor growth of breast cancer in mice $[31,34,40]$, inhibit murine xenograft growth of classical Hodgkin lymphoma [37], and inhibit the CCL5-dependent migration and invasion of ESCC cell lines [38]. Many other types of CCR5 antagonists and inhibitors such as Vicriviroc, TAK-779, Met-CCL5 (Met-RANTES), OTR4120, OTR4131, anibamine, and DT-13 were also reported to inhibit the cell migration, invasion and/or metastasis of various malignancies including breast cancer, gastric cancer, pancreatic cancer and hepatocellular carcinoma in preclinical studies [34, 69].

In conclusion, TAMs and ESCC cells express and secrete CCL3. CCL3 contributes to tumor progression and poor prognosis in ESCC patients by binding CCR5 on ESCC cells, activating PI3K/Akt and MEK/ERK pathways, upregulating MMP-2 and VEGF-A expression, and promoting cell migration, invasion, and angiogenesis (Fig. 8). CCR5 antagonists, which are usually used for treating HIV, could also be effective agents for the control of ESCC progression.

Acknowledgements This work has supported by Grants-in-Aid for Scientific Research (17K08693 and 18K07015) from Japan Society for the Promotion of Science (JSPS). We thank Atsuko Kawashima, Yumi Hashimoto, Nobuo Kubo, and Miki Yamazaki for their excellent technical assistance.

\section{Compliance with ethical standards}

Conflict of interest The authors declare that they have no conflict of interest.

Publisher's note Springer Nature remains neutral with regard to jurisdictional claims in published maps and institutional affiliations.
Open Access This article is licensed under a Creative Commons Attribution 4.0 International License, which permits use, sharing, adaptation, distribution and reproduction in any medium or format, as long as you give appropriate credit to the original author(s) and the source, provide a link to the Creative Commons license, and indicate if changes were made. The images or other third party material in this article are included in the article's Creative Commons license, unless indicated otherwise in a credit line to the material. If material is not included in the article's Creative Commons license and your intended use is not permitted by statutory regulation or exceeds the permitted use, you will need to obtain permission directly from the copyright holder. To view a copy of this license, visit http://creativecommons. org/licenses/by/4.0/.

\section{References}

1. Bray F, Ferlay J, Soerjomataram I, Siegel RL, Torre LA, Jemal A. Global cancer statistics 2018: GLOBOCAN estimates of incidence and mortality worldwide for 36 cancers in 185 countries. CA Cancer J Clin. 2018;68:394-424.

2. Malhotra GK, Yanala U, Ravipati A, Follet M, Vijayakumar M, Are C. Global trends in esophageal cancer. J Surg Oncol. 2017;115:564-79.

3. Tachimori Y, Ozawa S, Numasaki H, Ishihara R, Matsubara H, Muro K, et al. Comprehensive registry of esophageal cancer in Japan, 2012. Esophagus. 2019;16:221-45.

4. Wang H, Deng F, Liu Q, Ma Y. Prognostic significance of lymph node metastasis in esophageal squamous cell carcinoma. Pathol Res Pract. 2017;213:842-7.

5. Emi M, Hihara J, Hamai Y, Furukawa T, Ibuki Y, Okada M. Clinicopathologic features of submucosal esophageal squamous cell carcinoma. Ann Thorac Surg. 2017;104:1858-64.

6. Li H, Fan X, Houghton J. Tumor microenvironment: the role of the tumor stroma in cancer. J Cell Biochem. 2007;101:805-15.

7. Lin EW, Karakasheva TA, Hicks PD, Bass AJ, Rustgi AK. The tumor microenvironment in esophageal cancer. Oncogene. 2016;35:5337-49.

8. Mantovani A, Sozzani S, Locati M, Allavena P, Sica A. Macrophage polarization: tumor-associated macrophages as a paradigm for polarized M2 mononuclear phagocytes. Trends Immunol. 2002;23:549-55.

9. Mantovani A, Schioppa T, Porta C, Allavena P, Sica A. Role of tumor-associated macrophages in tumor progression and invasion. Cancer Metastasis Rev. 2006;25:315-22.

10. Yokozaki H, Koma YI, Shigeoka M, Nishio M. Cancer as a tissue: the significance of cancer-stromal interactions in the development, morphogenesis and progression of human upper digestive tract cancer. Pathol Int. 2018;68:334-52.

11. Takeya M, Komohara Y. Role of tumor-associated macrophages in human malignancies: friend or foe? Pathol Int. 2016;66:491-505.

12. Shigeoka M, Urakawa N, Nakamura T, Nishio M, Watajima T, Kuroda D, et al. Tumor associated macrophage expressing CD204 is associated with tumor aggressiveness of esophageal squamous cell carcinoma. Cancer Sci. 2013;104:1112-9.

13. Urakawa N, Utsunomiya S, Nishio M, Shigeoka M, Takase N, Arai N, et al. GDF15 derived from both tumor-associated macrophages and esophageal squamous cell carcinomas contributes to tumor progression via Akt and Erk pathways. Lab Investig. 2015;95:491-503.

14. Takase N, Koma Y, Urakawa N, Nishio M, Arai N, Akiyama H, et al. NCAM- and FGF-2-mediated FGFR1 signaling in the tumor microenvironment of esophageal cancer regulates the survival and migration of tumor-associated macrophages and cancer cells. Cancer Lett. 2016;380:47-58. 
15. Hosono M, Koma YI, Takase N, Urakawa N, Higashino N, Suemune K, et al. CXCL8 derived from tumor-associated macrophages and esophageal squamous cell carcinomas contributes to tumor progression by promoting migration and invasion of cancer cells. Oncotarget. 2017;8:106071-88.

16. Menten P, Wuyts A, Van Damme J. Macrophage inflammatory protein-1. Cytokine Growth Factor Rev. 2002;13:455-81.

17. Yang X, Lu P, Fujii C, Nakamoto Y, Gao JL, Kaneko S, et al. Essential contribution of a chemokine, CCL3, and its receptor, CCR1, to hepatocellular carcinoma progression. Int J Cancer. 2006;118:1869-76.

18. Abe M, Hiura K, Wilde J, Moriyama K, Hashimoto T, Ozaki S, et al. Role for macrophage inflammatory protein (MIP)- $1 \alpha$ and MIP-1 $\beta$ in the development of osteolytic lesions in multiple myeloma. Blood. 2002;100:2195-202.

19. Tsubaki M, Kato C, Manno M, Ogaki M, Satou T, Itoh T, et al. Macrophage inflammatory protein- $1 \alpha$ (MIP-1 $\alpha)$ enhances a receptor activator of nuclear factor $\kappa \mathrm{B}$ ligand (RANKL) expression in mouse bone marrow stromal cells and osteoblasts through MAPK and PI3K/Akt pathways. Mol Cell Biochem. 2007;304:53-60.

20. Wu Y, Li YY, Matsushima K, Baba T, Mukaida N. CCL3-CCR5 axis regulates intratumoral accumulation of leukocytes and fibroblasts and promotes angiogenesis in murine lung metastasis process. J Immunol. 2008;181:6384-93.

21. Hsu CJ, Wu MH, Chen CY, Tsai CH, Hsu HC, Tang CH. AMPactivated protein kinase activation mediates CCL3-induced cell migration and matrix metalloproteinase-2 expression in human chondrosarcoma. Cell Commun Signal. 2013;11:68.

22. Sasaki S, Baba T, Shinagawa K, Matsushima K, Mukaida N. Crucial involvement of the CCL3-CCR5 axis-mediated fibroblast accumulation in colitis-associated carcinogenesis in mice. Int $\mathrm{J}$ Cancer. 2014;135:1297-306.

23. Liao YY, Tsai HC, Chou PY, Wang SW, Chen HT, Lin YM, et al. CCL3 promotes angiogenesis by dysregulation of miR-374b/ VEGF-A axis in human osteosarcoma cells. Oncotarget. 2016;7:4310-25.

24. Baba T, Naka K, Morishita S, Komatsu N, Hirao A, Mukaida N. MIP-1 $\alpha / C C L 3-m e d i a t e d$ maintenance of leukemia-initiating cells in the initiation process of chronic myeloid leukemia. J Exp Med. 2013;210:2661-73.

25. Baba T, Tanabe Y, Yoshikawa S, Yamanishi Y, Morishita S, Komatsu N, et al. MIP-1 $\alpha / C C L 3$-expressing basophil-lineage cells drive the leukemic hematopoiesis of chronic myeloid leukemia in mice. Blood. 2016;127:2607-17.

26. Silva TA, Ribeiro FL, Oliveira-Neto HH, Watanabe S, Alencar Rde C, Fukada SY, et al. Dual role of CCL3/CCR1 in oral squamous cell carcinoma: implications in tumor metastasis and local host defense. Oncol Rep. 2007;18:1107-13.

27. da Silva JM, Moreira Dos Santos TP, Sobral LM, Queiroz-Junior CM, Rachid MA, Proudfoot AEI, et al. Relevance of CCL3/CCR5 axis in oral carcinogenesis. Oncotarget. 2017;8:51024-36.

28. Oppermann M. Chemokine receptor CCR5: insights into structure, function, and regulation. Cell Signal. 2004;16:1201-10.

29. Signoret N, Hewlett L, Wavre S, Pelchen-Matthews A, Oppermann M, Marsh M. Agonist-induced endocytosis of CC chemokine receptor 5 is clathrin dependent. Mol Biol Cell. 2005;16:902-17.

30. Longden J, Cooke EL, Hill SJ. Effect of CCR5 receptor antagonists on endocytosis of the human CCR5 receptor in CHO-K1 cells. Br J Pharmacol. 2008;153:1513-27.

31. Velasco-Velazquez M, Jiao X, De La Fuente M, Pestell TG, Ertel A, Lisanti MP, et al. CCR5 antagonist blocks metastasis of basal breast cancer cells. Cancer Res. 2012;72:3839-50.
32. Zhang W, Xu J, Fang H, Tang L, Chen W, Sun Q, et al. Endothelial cells promote triple-negative breast cancer cell metastasis via PAI-1 and CCL5 signaling. Faseb J. 2018;32:276-88.

33. Jin K, Pandey NB, Popel AS. Simultaneous blockade of IL-6 and CCL5 signaling for synergistic inhibition of triple-negative breast cancer growth and metastasis. Breast Cancer Res. 2018;20:54.

34. Jiao X, Velasco-Velazquez MA, Wang M, Li Z, Rui H, Peck AR, et al. CCR5 governs DNA damage repair and breast cancer stem cell expansion. Cancer Res. 2018;78:1657-71.

35. Singh SK, Mishra MK, Eltoum IA, Bae S, Lillard JW Jr., Singh R. CCR5/CCL5 axis interaction promotes migratory and invasiveness of pancreatic cancer cells. Sci Rep. 2018;8:1323.

36. Gao T, Shen Z, Ma C, Li Y, Kang X, Sun M. The CCL5/CCR5 chemotactic pathway promotes perineural invasion in salivary adenoid cystic carcinoma. J Oral Maxillofac Surg. 2018;76:1708-18.

37. Casagrande N, Borghese C, Visser L, Mongiat M, Colombatti A, Aldinucci D. CCR5 antagonism by maraviroc inhibits Hodgkin lymphoma microenvironment interactions and xenograft growth. Haematologica. 2019;104:564-75.

38. Wu YC, Shen YC, Chang JW, Hsieh JJ, Chu Y, Wang CH. Autocrine CCL5 promotes tumor progression in esophageal squamous cell carcinoma in vitro. Cytokine. 2018;110:94-103.

39. Schlecker E, Stojanovic A, Eisen C, Quack C, Falk CS, Umansky $\mathrm{V}$, et al. Tumor-infiltrating monocytic myeloid-derived suppressor cells mediate CCR5-dependent recruitment of regulatory T cells favoring tumor growth. J Immunol. 2012;189:5602-11.

40. Halvorsen EC, Hamilton MJ, Young A, Wadsworth BJ, LePard $\mathrm{NE}$, Lee HN, et al. Maraviroc decreases CCL8-mediated migration of CCR5 + regulatory $\mathrm{T}$ cells and reduces metastatic tumor growth in the lungs. Oncoimmunology. 2016;5:e1150398.

41. You Y, Li Y, Li M, Lei M, Wu M, Qu Y, et al. Ovarian cancer stem cells promote tumour immune privilege and invasion via CCL5 and regulatory T cells. Clin Exp Immunol. 2018;191:60-73.

42. Stoner GD, Kaighn ME, Reddel RR, Resau JH, Bowman D, Naito $\mathrm{Z}$, et al. Establishment and characterization of SV40 T-antigen immortalized human esophageal epithelial cells. Cancer Res. 1991;51:365-71.

43. Nishihira T, Hashimoto $\mathrm{Y}$, Katayama M, Mori S, Kuroki T. Molecular and cellular features of esophageal cancer cells. J Cancer Res Clin Oncol. 1993;119:441-9.

44. Japan Esophageal Society. Japanese classification of esophageal cancer, 11th edition: part I. Esophagus. 2017;14:1-36.

45. Japan Esophageal Society. Japanese classification of esophageal cancer, 11th edition: part II and III. Esophagus. 2017;14:37-65.

46. TNM Classification of Malignant Tumours: Eighth Edition: Wiley-Blackwell, 2017.

47. Chen MF, Lu MS, Chen PT, Chen WC, Lin PY, Lee KD. Role of interleukin 1 beta in esophageal squamous cell carcinoma. J Mol Med. 2012;90:89-100.

48. Zhou J, Zheng S, Liu T, Liu Q, Chen Y, Tan D, et al. IL-1 $\beta$ from M2 macrophages promotes migration and invasion of ESCC cells enhancing epithelial-mesenchymal transition and activating NF$\kappa \mathrm{B}$ signaling pathway. J Cell Biochem. 2018;119:7040-52.

49. Ottonello L, Montecucco F, Bertolotto M, Arduino N, Mancini M, Corcione A, et al. CCL3 (MIP-1 $\alpha$ ) induces in vitro migration of GM-CSF-primed human neutrophils via CCR5-dependent activation of ERK 1/2. Cell Signal. 2005;17:355-63.

50. Alessi DR, James SR, Downes CP, Holmes AB, Gaffney PR, Reese $\mathrm{CB}$, et al. Characterization of a 3-phosphoinositidedependent protein kinase which phosphorylates and activates protein kinase Balpha. Curr Biol. 1997;7:261-9.

51. Sarbassov DD, Guertin DA, Ali SM, Sabatini DM. Phosphorylation and regulation of $\mathrm{Akt} / \mathrm{PKB}$ by the rictor-mTOR complex. Science. 2005;307:1098-101. 
52. Zhang J, Yang D, Huang H, Sun Y, Hu Y. Coordination of necessary and permissive signals by PTEN inhibition for CNS axon regeneration. Front Neurosci. 2018;12:558.

53. Asati V, Mahapatra DK, Bharti SK. PI3K/Akt/mTOR and Ras/ Raf/MEK/ERK signaling pathways inhibitors as anticancer agents: Structural and pharmacological perspectives. Eur J Med Chem. 2016;109:314-41.

54. Kashyap T, Pramanik KK, Nath N, Mishra P, Singh AK, Nagini $\mathrm{S}$, et al. Crosstalk between Raf-MEK-ERK and PI3K-Akt-GSK3 $\beta$ signaling networks promotes chemoresistance, invasion/migration and stemness via expression of CD44 variants (v4 and v6) in oral cancer. Oral Oncol. 2018;86:234-43.

55. Li B, Tsao SW, Li YY, Wang X, Ling MT, Wong YC, et al. Id-1 promotes tumorigenicity and metastasis of human esophageal cancer cells through activation of PI3K/AKT signaling pathway. Int J Cancer. 2009;125:2576-85.

56. Liu F, Zheng S, Liu T, Liu Q, Liang M, Li X, et al. MicroRNA-21 promotes the proliferation and inhibits apoptosis in Eca109 via activating ERK1/2/MAPK pathway. Mol Cell Biochem. 2013;381:115-25.

57. Tian B, Chen X, Zhang H, Li X, Wang J, Han W, et al. Urokinase plasminogen activator secreted by cancer-associated fibroblasts induces tumor progression via PI3K/AKT and ERK signaling in esophageal squamous cell carcinoma. Oncotarget. 2017;8:42300-13.

58. Samantaray S, Sharma R, Chattopadhyaya TK, Gupta SD, Ralhan R. Increased expression of MMP-2 and MMP-9 in esophageal squamous cell carcinoma. J Cancer Res Clin Oncol. 2004;130:37-44.

59. Li Y, Ma J, Guo Q, Duan F, Tang F. Zheng P, et al. Overexpression of MMP-2 and MMP-9 in esophageal squamous cell carcinoma. Dis Esophagus. 2009;22:664-7.

60. Zhao ZH, Tian Y, Yang JP, Zhou J, Chen KS. RhoC, vascular endothelial growth factor and microvascular density in esophageal squamous cell carcinoma. World J Gastroenterol. 2015;21:905-12.
61. Wang C, Wang J, Chen Z, Gao Y, He J. Immunohistochemical prognostic markers of esophageal squamous cell carcinoma: a systematic review. Chin J Cancer. 2017;36:65.

62. Li CH, Sun XJ, Niu SS, Yang CY, Hao YP, Kou JT, et al. Overexpression of IQGAP1 promotes the angiogenesis of esophageal squamous cell carcinoma through the AKT and ERKmediated VEGF-VEGFR2 signaling pathway. Oncol Rep. 2018;40:1795-802.

63. Gao Y, Guan Z, Chen J, Xie H, Yang Z, Fan J, et al. CXCL5/ CXCR2 axis promotes bladder cancer cell migration and invasion by activating PI3K/AKT-induced upregulation of MMP2/MMP9. Int J Oncol. 2015;47:690-700.

64. Wang X, Li X, Li C, He C, Ren B, Deng Q, et al. Aurora-A modulates MMP-2 expression via AKT/NF-kB pathway in esophageal squamous cell carcinoma cells. Acta Biochim Biophys Sin. 2016;48:520-7.

65. Muscella A, Cossa LG, Vetrugno C, Antonaci G, Marsigliante S. Adenosine diphosphate regulates MMP2 and MMP9 activity in malignant mesothelioma cells. Ann N Y Acad Sci. 2018;1431:72-84.

66. Sivina M, Hartmann E, Kipps TJ, Rassenti L, Krupnik D, Lerner $\mathrm{S}$, et al. CCL3 (MIP-1 $\alpha$ ) plasma levels and the risk for disease progression in chronic lymphocytic leukemia. Blood. 2011;117:1662-9.

67. Takahashi K, Sivina M, Hoellenriegel J, Oki Y, Hagemeister FB, Fayad L, et al. CCL3 and CCL4 are biomarkers for B cell receptor pathway activation and prognostic serum markers in diffuse large $\mathrm{B}$ cell lymphoma. $\mathrm{Br} \quad \mathrm{J}$ Haematol. 2015;171:726-35.

68. Xing Q, Xie H, Zhu B, Sun Z, Huang Y. MiR-455-5p suppresses the progression of prostate cancer by targeting CCR5. Biomed Res Int. 2019;2019:6394784.

69. Aldinucci D, Casagrande N. Inhibition of the CCL5/CCR5 axis against the progression of gastric cancer. Int $\mathrm{J}$ Mol Sci. 2018;19:1477. 